\title{
Non-Newly Generated, "Immature" Neurons in the Sheep Brain Are Not Restricted to Cerebral Cortex
}

\author{
Matteo Piumatti, ${ }^{1 \star}$ Ottavia Palazzo, ${ }^{1 \star}$ Chiara La Rosa,,${ }^{1,2}$ Paola Crociara, ${ }^{1}$ - Roberta Parolisi, ${ }^{1}$ Federico Luzzati, ${ }^{1,3}$ \\ Frederic Lévy, ${ }^{4}$ and Luca Bonfanti ${ }^{1,2}$ \\ ${ }^{1}$ Neuroscience Institute Cavalieri Ottolenghi, Orbassano, Italy, ${ }^{2}$ Department of Veterinary Sciences, University of Turin, Torino, Italy, ${ }^{3}$ Department of Life \\ Sciences and Systems Biology, University of Turin, Italy, ${ }^{4}$ Unité Mixte de Recherche, Institut National de la Recherche Agronomique, Centre National de la \\ Recherche Scientifique/Universitè F. Rabelais, Institut Francais du Cheval et de l'Equitation, Physiologie de la Reproduction et des Comportements, \\ Nouzilly, France
}

A newly proposed form of brain structural plasticity consists of non-newly generated, "immature" neurons of the adult cerebral cortex. Similar to newly generated neurons, these cells express the cytoskeletal protein Doublecortin (DCX), yet they are generated prenatally and then remain in a state of immaturity for long periods. In rodents, the immature neurons are restricted to the paleocortex, whereas in other mammals, they are also found in neocortex. Here, we analyzed the DCX-expressing cells in the whole sheep brain of both sexes to search for an indicator of structural plasticity at a cellular level in a relatively large-brained, long-living mammal. Brains from adult and newborn sheep (injected with BrdU and analyzed at different survival times) were processed for DCX, cell proliferation markers (Ki-67, BrdU), pallial/subpallial developmental origin $(\mathrm{Tbr} 1, S p 8)$, and neuronal/glial antigens for phenotype characterization. We found immature-like neurons in the whole sheep cortex and in large populations of DCX-expressing cells within the external capsule and the surrounding gray matter (claustrum and amygdala). BrdU and Ki-67 detection at neonatal and adult ages showed that all of these DCX ${ }^{+}$cells were generated during embryogenesis, not after birth. These results show that the adult sheep, unlike rodents, is largely endowed with non-newly generated neurons retaining immature features, suggesting that such plasticity might be particularly important in largebrained, long-living mammals.

Key words: cerebral cortex; doublecortin; immature neurons; plasticity; postnatal development

\section{Significance Statement}

Brain plasticity is important in adaptation and brain repair. Structural changes span from synaptic plasticity to adult neurogenesis, the latter being highly reduced in large-brained, long-living mammals (e.g., humans). The cerebral cortex contains "immature" neurons, which are generated prenatally and then remain in an undifferentiated state for long periods, being detectable with markers of immaturity. We studied the distribution and developmental origin of these cells in the whole brain of sheep, relatively large-brained, long-living mammals. In addition to the expected cortical location, we also found populations of non-newly generated neurons in several subcortical regions (external capsule, claustrum, and amygdala). These results suggests that nonneurogenic, parenchymal structural plasticity might be more important in large mammals with respect to adult neurogenesis.

\section{Introduction}

The mammalian CNS is made up mostly of nonrenewable (perennial) neurons with cell processes that are connected physically

Received June 26, 2017; revised 0ct. 24, 2017; accepted Nov. 16, 2017.

Author contributions: F. Luzzati and L.B. designed research; M.P., O.P., C.L.R., and P.C. performed research; F. Lévy and L.B. contributed unpublished reagents/analytic tools; M.P., O.P., C.L.R., R.P., F. Luzzati, F. Lévy, and L.B. analyzed data; L.B. wrote the paper.

This work was supported by MIUR-PRIN2015 (Grant 2015Y5W9YP), the University of Turin (doctoral program in veterinary sciences), Fondazione (RT (Bando Ricerca e Istruzione 2014), and the French Agence Nationale pour la Recherche (PLASTMATBEHAV ANR12-BSV7-0017). We thank the Istituto Zooprofilattico del Piemonte, Liguria e Valle D'Aosta, and Dr. Alessandra Pecora for technical help in the first phases of the study.

*M.P. and O.P. contributed equally to this work. and functionally in a largely invariant way. Although anatomical invariability is a necessary requisite to ensure stability of connections in the neural circuits (Frotscher, 1992), exceptions do exist in the form of cellular modifications referred to as "structural

M. Piumatti's present address: Université Libre de Bruxelles (ULB), Institute for Interdisciplinary Research (IRIBHM), Belgium.

P. Crociara's present address: Istituto Zooprofilattico Sperimentale del Piemonte Liguria e Valle d'Aosta, Torino, Italy.

Correspondence should be addressed to Dr. Luca Bonfanti, Department of Veterinary Sciences, Largo Braccini 2 , 10095 Grugliasco (T0), University of Turin, Italy. E-mail: luca.bonfanti@unito.it.

DOI:10.1523/JNEUROSCI.1781-17.2017

Copyright $\odot 2018$ the authors $\quad 0270-6474 / 18 / 380826-17 \$ 15.00 / 0$ 
plasticity," which affect the brain anatomy at different levels and degrees (Bonfanti, 2006; Theodosis et al., 2008). These exceptions span from formation/elimination of synapses in preexisting neurons (synaptic plasticity; Bonfanti-and Theodosis, 2009; Bailey et al., 2015) to addition/replacement of new neurons (adult neurogenesis; Bonfanti-and Peretto, 2011; Aimone et al., 2014). The occurrence, amount, type, and location of neural structural plasticity, as well as its reparative capacity, vary greatly in the animal world (Bonfanti-and Peretto, 2011; Grandel and Brand, 2013) and, to a lesser extent, among mammals (Feliciano et al., 2015; Lipp and Bonfanti, 2016). The cytoskeletal protein doublecortin (DCX) is an excellent marker for cells that retain high potential for structural plasticity in the CNS (Gleeson et al., 1999; Nacher et al., 2001). Due to its heavy expression in newly generated neuroblasts and during the early phases of their migration/differentiation, DCX is commonly used as a marker for adult neurogenesis (Brown et al., 2003). Nevertheless, it is now clear that at least one type of the neurons located in layer II of the adult mammalian cerebral cortex that are not newly generated ("immature neurons"; Gomez-Climent et al., 2008) express DCX during adulthood (for review, see Bonfanti-and Nacher, 2012; Nacher and Bonfanti, 2015). Current data indicate that the occurrence and distribution of $\mathrm{DCX}^{+}$cells can vary substantially in brain regions of different mammals (Feliciano et al., 2015; Lipp and Bonfanti, 2016), suggesting species-specific heterogeneity in their capability to undergo both neurogenic and non-neurogenic structural plasticity. For instance, the rate of adult neurogenesis decreases in mammals with extended life expectance (e.g., humans, dolphins, and sheep; Sanai et al., 2011; Brus et al., 2013a; Parolisi et al., $2015,2017)$ compared with the relatively short-living laboratory rodents (for review, see Lipp and Bonfanti, 2016; Paredes et al., 2016). In contrast, the occurrence of cortical layer II immature neurons is higher in rabbits, guinea pigs, and cats compared with rats and mice, extending into neocortical regions in the former and being restricted to paleocortex in the latter (Xiong et al., 2008; Cai et al., 2009; Luzzati et al., 2009). Here, the occurrence of $\mathrm{DCX}^{+}$cells was investigated in sheep (Ovis aries) with the idea of analyzing the distribution of this indicator of structural plasticity in a relatively long-living mammal endowed with a large-sized, gyrencephalic brain. Sheep possess a brain as large as a macaque monkey and have a similar life span (10/30 years in wild/captivity). In addition, experimental procedures such as BrdU injection for subsequent immunocytochemical detection of newly generated cells in the brain tissue can be performed in these animals. Neonatal and adult animals treated with BrdU (injected in pregnant ewes in the case of neonates) were studied to assess the time of genesis (prenatal vs postnatal) of the $\mathrm{DCX}^{+}$cells. We show that, in addition to cortical immature neurons, different populations of non-newly generated $\mathrm{DCX}^{+}$cells are present consistently in the external capsule and adjacent regions of the adult sheep brain. Interestingly, quantification of these latter cells in neonatal, prepubertal, and adult animals showed that they are not depleted by aging.

\section{Materials and Methods}

\section{Animals, BrdU injections, and tissue preparation}

Neonatal, prepubertal, and adult animals (breed: Ile de France) were raised at the Institut National de la Recherche Agronomique (INRA) research center (Nouzilly, Indre et Loire, France). Experiments were conducted on 9 adult (females, 2 year old), 3 prepubertal (males, 4 month old), and 7 neonatal ( 4 males, 3 females, 1 week old) sheep (Table 1). Adult ewes were housed in an individual pen $(2 \times 1 \mathrm{~m})$ and received four intravenous injections of BrdU during pregnancy (1 injection/d, 20 $\mathrm{mg} / \mathrm{kg}$ in $0.9 \%$ saline; Sigma-Aldrich), a thymidine analog incorporated
Table 1. Animals used in the present study

\begin{tabular}{lllll}
\hline Source & Sex & Breed & Age & BrdU treatment \\
\hline INRA & $4 \mathrm{M}, 3 \mathrm{~F}$ & Ile-de-France & Neonate $(7 \mathrm{~d})$ & $\begin{array}{c}\text { Survival: } 97 \mathrm{~d} \text { (injection: } \\
\end{array}$ \\
& & & $90 \mathrm{~d}$ prepartum) \\
& $3 \mathrm{M}$ & & Prepubertal $(4 \mathrm{mo})$ & - \\
& & & Adult $(2 \mathrm{y})$ & Survival: $120 \mathrm{~d}$ \\
& & & Survival: $60 \mathrm{~d}$ \\
& & & Survival: $30 \mathrm{~d}$ \\
\hline
\end{tabular}

into the DNA during the S-phase of the mitotic division. Two days after lambing, ewes were anesthetized with thiopental and decapitated by a licensed butcher in an official slaughterhouse (ethical permissions are reported in Brus et al., 2013b). Three different survival times were analyzed in these adult animals: 1, 2, and 4 months (Brus et al., $2013 \mathrm{~b}$ ). Because all of the ewes were pregnant, the intravenous injections of BrdU could allow the molecule to pass to the fetuses and be incorporated into their brains. All lambs used in this study were collected from mothers being injected 3 months before parturition (i.e., at 2 month gestational days). Brains were perfused through both carotid arteries with $2 \mathrm{~L}$ of $1 \%$ sodium nitrite in phosphate buffer saline, followed by $4 \mathrm{~L}$ of ice-cold $4 \%$ paraformaldehyde solution in $0,1 \mathrm{M}$ phosphate buffer, $\mathrm{pH}$ 7.4. The brains were then dissected out, cut into blocks, and postfixed in the same fixative for $48 \mathrm{~h}$. The tissues were then stored in $30 \%$ sucrose. Each hemisphere was cut into 4 coronal slices $(\sim 1.5 \mathrm{~cm}$ thick), embedded in optimum cutting temperature medium (BioOptica), frozen in isopentane, and stored at $-80^{\circ} \mathrm{C}$. Cryostat coronal sections ( $40 \mu \mathrm{m}$ thick) were cut to be used in free-floating immunohistochemistry and immunofluorescence procedures. We then obtained the outlines of four levels of interest, representing the whole sheep brain (L1-L4) by combining the analysis of our cryostat sections and photographs from the atlas of Brain Biodiversity Bank of Michigan State University (Fig. 1).

\section{Immunohistochemistry}

Immunohistochemical reactions were performed on free-floating sections; when necessary, antigen retrieval was performed using citric acid at $90^{\circ} \mathrm{C}$ for $5-10 \mathrm{~min}$. The section were incubated in blocking buffer $(2 \%$ normal serum, $0.5-1 \%$ Triton X-100 in $0.01 \mathrm{M}$ PBS, $\mathrm{pH} 7.4$ ) for $2 \mathrm{~h}$ at room temperature, then incubated for $24-48 \mathrm{~h}$ at $4^{\circ} \mathrm{C}$ in a solution of 0.01 m PBS, pH 7.4, containing 0,5-1\% Triton X-100, 2\% normal serum, and the primary antibodies (Table 2). Sections were then incubated with appropriate solutions of secondary antibody: Alexa Fluor 488-conjugated goat anti-mouse (1:400; Invitrogen), Alexa Fluor 488-conjugated goat anti-rabbit (1: 400; Invitrogen), Alexa Fluor 488-conjugated donkey anti-rat (1:400 Jackson ImmunoResearch), Alexa Fluor-555-conjugated goat anti-mouse (1:800; Invitrogen), Alexa Fluor-555-conjugated goat anti-rabbit (1:800; Invitrogen), Alexa Fluor-555-conjugated goat anti-guinea pig (1:800; Invitrogen), cyanine 3 (cy3)-conjugated goat anti-mouse (1:800; Jackson ImmunoResearch), cyanine 3 (cy3)-conjugated goat anti-rabbit (1:800; Jackson ImmunoResearch), cyanine 3 (cy3)-conjugated donkey anti-goat (1:800,Jackson ImmunoResearch), Alexa Fluor-647conjugated donkey anti-mouse (1: 800; Jackson ImmunoResearch), and Alexa Fluor-647-conjugated donkey anti-rabbit, for $3 \mathrm{~h}$ at room temperature (RT). Sections were counterstained with 4',6-diamidino-2-phenylindole (DAPI; KPL), coverslipped with MOWIOL 4-88 (Calbiochem), and examined. For $3,3^{\prime}$-diaminobenzidine (DAB) immunohistochemistry, sections were incubated in a solution of $0,3 \% \mathrm{H} 2 \mathrm{O} 2$ in $0,01 \mathrm{M} \mathrm{PBS}, \mathrm{pH} 7.4$, for $15 \mathrm{~min}$ to inhibit the endogenous peroxidase before incubation with blocking buffer. After primary antibody incubation, sections were incubated with goat anti-rabbit IgG biotinylated secondary antibody (1:350; Vector Laboratories) or horse anti-goat IgG biotinylated secondary antibody (1:250; Vector Laboratories) for $2 \mathrm{~h}$ at RT. Sections were washed and incubated in avidin-biotin-peroxidase complex (Vectastain ABC kit; Vector Laboratories) for $2 \mathrm{~h}$ at RT. The reaction was developed with the DAB Peroxidase Substrate Kit (Vector Laboratories) for 3-5 min. Sections were mounted on 3-aminopropyl-triethoxysilan-treated slides and then counterstained with $1 \%$ cresyl violet acetate solution (1-2 min exposure) and coverslipped with Neo-Mont 109016 (Merck). 
Quantitative analyses

Cell counting was performed using Neurolucida software (MicroBrightfield).

Diameters of $\mathrm{DCX}^{+}$objects in the external capsule and pericapsular regions. The average object diameter (orthogonal to main axis) was measured for all clusters and groups of scattered cells in the external capsule, claustrum, and amygdala of three adult animals using the straight line tool of ImageJ program after a proper calibration and then reporting the minimum and maximum length to obtain a size range. (For more information, see the Results section.)

Density of $\mathrm{DCX}^{+}$objects in the external capsule at neonatal and adult ages. The $\mathrm{DCX}^{+}$cell clusters and groups were counted in the whole extension of the external capsule in three adult and three newborn animals using a serial step of 12 cryostat sections ( $480 \mu \mathrm{m}$; 11 sections for the adult and 10 for the newborn). The density was calculated as the total number of objects/area $\left(\mathrm{mm}^{2}\right)$. A 3D reconstruction was made to further characterize the $\mathrm{DCX}^{+}$clusters in the adult in the posterior part of the external capsule (24 serial cryostat sections, $40 \mu \mathrm{m}$ thick, corresponding to $0.96 \mathrm{~mm}$ of white matter tissue).

Cell density in the amygdala and claustrum at neonatal and adult ages. The total $\mathrm{DCX}^{+}$cells present within the two pericapsular regions was counted in three adult and three newborn animals (three slices corresponding to the anterior, middle, and posterior part of each anatomical structure were considered). The density was calculated as the total number of cells/ area (in square millimeters).

Linear density of $\mathrm{DCX}^{+}$neurons in the cerebral cortex at neonatal and adult ages. The DCX ${ }^{+}$ cells present in the cortical layer II were counted within two brain levels (L2 and L3) and three regions (the cingulate cortex, the medial margin of the suprasylvian gyrus in the neocortex, and the piriform cortex in the paleocortex; see Fig. 6) using three cryostat sections/level in three adult and three newborn animals. The linear density was calculated as the total number of cells/the cortical tract length (in millimeters).

Cell soma diameters of $\mathrm{DCX}{ }^{+}$cells. The average cell soma diameter (orthogonal to main axis) was measured for 200 cells in the cortex, claustrum, and amygdala of three adult animals using the straight line tool of ImageJ after a proper calibration and then reporting the minimum and maximum length to obtain a size range.

$D C X^{+} / B r d U^{+}$double staining. The percentage of double-stained cells was calculated after analyzing 200 cells in the cortex, claustrum, external capsule, and amygdala of 3 newborn animals (number of $\mathrm{DCX}^{+} / \mathrm{BrdU}^{+}$cell of DCX ${ }^{+}$, singlestained cells) and 3 adult animals (for each survival time: 1,2 , and 4 months).

$\mathrm{DCX}^{+} / \mathrm{NeuN}^{+}$double staining. The percentage of double-stained cells was calculated after analyzing 200 cells in the cortex, claustrum, and amygdala of three adult animals (number of $\mathrm{DCX}^{+} / \mathrm{NeuN}^{+}$cells of $\mathrm{DCX}^{+}$, single-stained cells).

$\mathrm{DCX}^{+} / \mathrm{Tbr} 1^{+}$and $\mathrm{DCX} \mathrm{X}^{+} / \mathrm{Sp} 8^{+}$double staining. The percentage of doublestained cells was calculated after analyzing 200 cells in the cortex, external
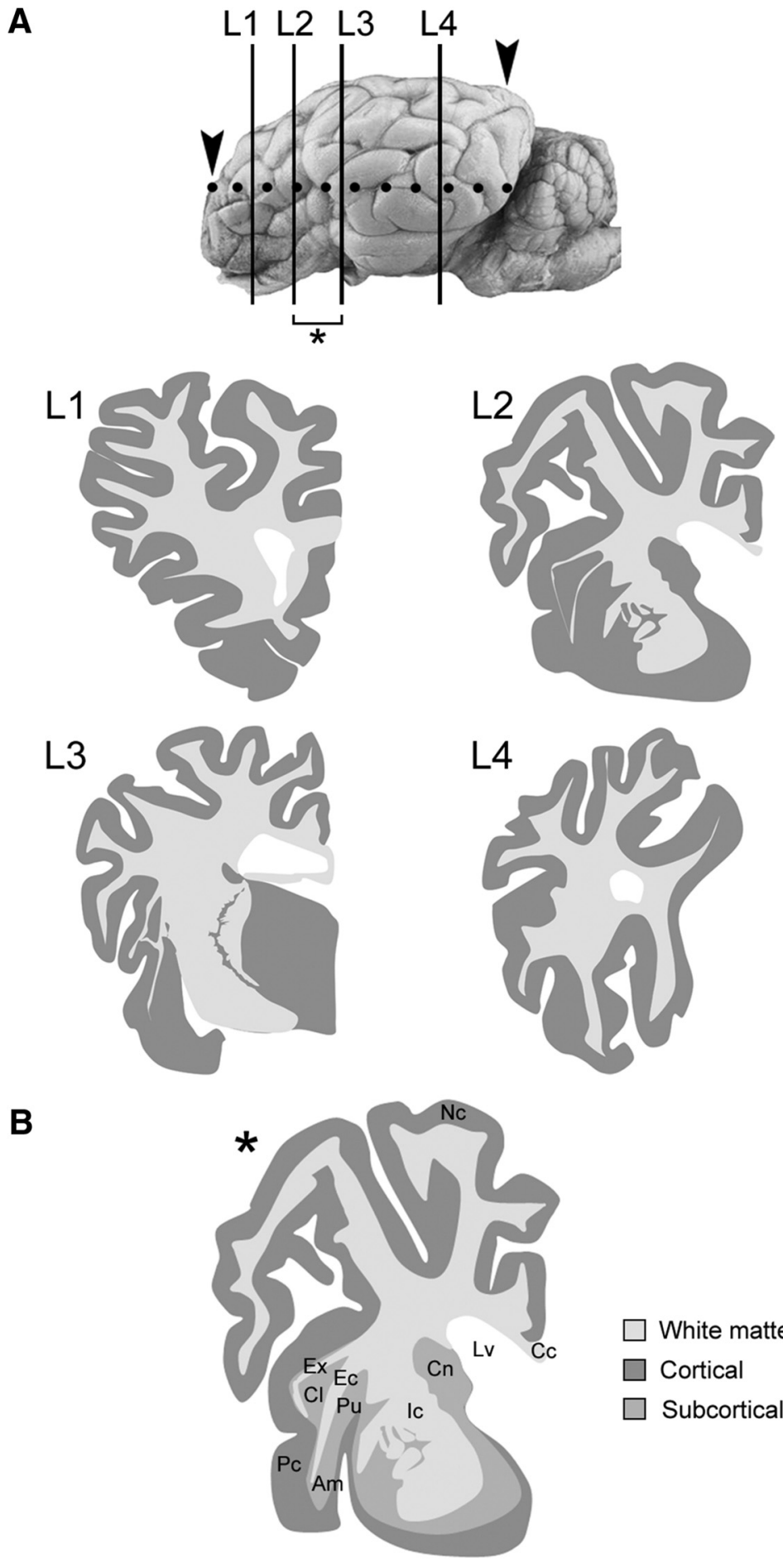

$\square$ White matter
$\square$ Cortical
$\square$ Subcortical

Figure 1. A, Four levels of interest (L1-L4) in the whole sheep brain, obtained by redrawing the Atlas of Brain Biodiversity Bank (Michigan State University; https://msu.edu/ brains/brains/sheep/index.html) and adapted to our cryostat sections; the whole extension of the brain analyzed is comprised between the arrowheads (dotted line). $\boldsymbol{B}$, By combining levels L2 and L3, an additional, "ideal" level containing the most important neuroanatomical structures analyzed here was obtained (asterisk); this ideal level was used to represent Results. This representation refers to adult animals, yet no significant morphological/neuroanatomical differences were observed in younger animals. Nc, Neocortex; Pc, paleocortex; Ic, internal capsule; Ec, external capsule; Ex, capsula extrema; Cl, claustrum; Am, amygdala; Pu, putamen; Cn, caudate nucleus; Lv, lateral ventricle; Cc, corpus callosum. capsule, claustrum, and amygdala of three newborn animals (number of $\mathrm{DCX}^{+} / \mathrm{Tbr} 1^{+}$or $\mathrm{DCX}{ }^{+} / S p 8^{+}$cells of $\mathrm{DCX}^{+}$, single-stained cells).

Statistical analysis. All graphics and relative statistical analysis were performed using GraphPad Prism 5 Software and included unpaired (two-tailed) Student's $t$ test (comparing only two groups) and two-way 
Table 2. Primary antibodies used in the present study

\begin{tabular}{lllll}
\hline Antigen & Host & Dilution & RRID & Source \\
\hline BrdU & Rat & $1: 300$ & AB_609566 & AbDSerotec \\
DCX & Rabbit & $1: 3000$ & AB_732011 & Abcam \\
& Goat & $1: 2000$ & AB_2088494 & Santa Cruz Biotechnology \\
& Guinea pig & $1: 1000$ & AB_2230227 & Abcam \\
GFAP & Rabbit & $1: 800$ & AB_10013382 & Agilent Technologies \\
& Mouse & $1: 200$ & AB_94844 & Millipore \\
Ki-67 & Mouse & $1: 500$ & AB_393778 & Agilent Technologies \\
NeuN & Mouse & $1: 1000$ & AB_177621 & Millipore \\
Sp8 & Rabbit & $1: 10000$ & AB_877304 & Millipore \\
Tbr1 & Rabbit & $1: 1000$ & AB_10806888 & Chemicon \\
PSA-NCAM & Mouse & $1: 1400$ & AB_95211 & Millipore \\
HuC/D & Mouse & $1: 800$ & AB_221448 & Invitrogen \\
CNGA3 & Rabbit & $1: 250$ & AB_2039822 & Alomone Labs \\
\hline
\end{tabular}

ANOVAs. $p<0.05$ was considered as statistically significant. Data are expressed as averages $\pm \mathrm{SD}$.

\section{Image acquisition and processing}

Images from immunofluorescence specimens were collected with a Leica TCS SP5 confocal microscope. Images from DAB immunohistochemistry were collected with a Nikon Eclipse $80 \mathrm{i}$ microscope connected to a color CCD Camera. Images were processed using Photoshop CS4 (Adobe Systems) and ImageJ. Only general adjustments to color, contrast, and brightness were made. The $3 \mathrm{D}$ reconstruction in the external capsule was performed using Neurolucida software (MicroBrightfield) by aligning 24 consecutive coronal sections starting from the onset of the thalamus. The sections were previously immunoreacted for DCX using DAB peroxidase staining and counterstained with $1 \%$ cresyl violet acetate solution.

\section{Results}

Distribution of $\mathrm{DCX}^{+}$cells in the adult sheep brain

After systematic screening of the whole adult sheep brain, several populations of $\mathrm{DCX}^{+}$cells were detected at different locations (Fig. 2): (1) newly generated neuroblasts/neuronal-like cells within the SVZ and hippocampal neural stem cell niches, (2) neuronal-like cells in the superficial layers of the cerebral cortex, and (3) groups of neuroblasts/neuronal-like cells in the external capsule and surrounding gray matter (claustrum and amygdaloid nuclei). No $\mathrm{DCX}^{+}$cells were detected in the striatum/putamen. In addition to their different location, these $\mathrm{DCX}^{+}$cells appeared to vary in their morphology and spatial organization (Fig. 2B,C). Cells in the neurogenic zones typically appeared as described previously (Brus et al., 2010, 2013b): single, elongated, bipolar neuroblasts in the SVZ adjacent to the lateral ventricle wall and at the lower aspect of the hippocampal dentate gyrus (Fig. 2D); these neurogenic regions were used as an internal control for detection of local cell division markers (Ki-67 antigen) and newly generated neurons identifiable through injection of exogenous markers (BrdU) and subsequent detection at different survival times.

\section{$\mathrm{DCX}^{+}$cells in the cerebral cortex}

As described previously in some cortical areas of other mammals (for review, see Bonfanti-and Nacher, 2012), DCX ${ }^{+}$neuronallike cells were detected in the cerebral cortex of the adult sheep (Fig. 3). These cells were present in the superficial layers of most paleocortex and neocortex (Fig. $3 A, B$ ). They were further characterized to use them as a population of $\mathrm{DCX}^{+}$cortical neurons that was described previously in other species and studied here in sheep. In the cortical cytoarchitecture, the $\mathrm{DCX}^{+}$neuronal-like cells were localized in the upper part of layer II (at the limit with layer I), being present along the entire anteroposterior and dorsoventral axis of the brain. They appeared to be more abundant in the piriform cortex (paleocortex) with respect to neocortex (Fig. $2 B$; see below for quantitative analysis). Two main morphological types falling into two cell body size categories were identified: small cells with a diameter of $4-7 \mu \mathrm{m}$ (type 1 cells) and large cells with a diameter of 9-12 $\mu \mathrm{m}$ (type 2 cells) (Fig. $3 C, D$ ). The largesized cells frequently appeared as pyramidal-like neurons ( similar to the "principal cells" previously described in rats by Gomez-Climent et al., 2008), whereas the small cells mostly showed a simpler, bipolar morphology (Fig. 3C,D). The principal cell type can be further split into two main patterns linked to soma shape and dendritic complexity: those with oval-shaped cell body and poorly ramified apical dendrites (here referred to as type $2 a$ ) and others with more developed apical dendrite arborization and basal dendrites (here referred to as type $2 \mathrm{~b}$ ) (Fig. 3C,D). Type 2 cells were far less abundant with respect to type 1 cells ( $\sim 7 \%$; Fig. $3 D)$.

\section{$\mathrm{DCX}^{+}$cells in the external capsule and surrounding regions}

Additional $\mathrm{DCX}^{+}$cell populations were detectable in the external capsule and surrounding regions (claustrum and amygdala). Most of these cells were grouped into discrete bulks to form either tightly packed cell clusters (mainly in the white matter; Fig. 2E) or groups of scattered cells (more frequently observed in gray matter; Fig. 2G). Due to their heterogeneity and to perform a quantitative analysis, they were considered as "DCX ${ }^{+}$objects" divided into compact cell clusters (within the external capsule) and groups of scattered cells (in the surrounding regions: amygdala and claustrum).

\section{External capsule}

Most $\mathrm{DCX}^{+}$cells in capsular white matter appeared as bipolar, elongated elements, often endowed with very long cell processes, which were assembled to form tightly packed cell clusters (Fig. $4 C$ ). These clusters showed remarkable diameter variability (between 50 and $380 \mu \mathrm{m}$ ). When observed in single coronal sections, some of them were reminiscent of the thick chains of neuroblasts described in the SVZ of rodents (Lois et al., 1996) and in the surrounding regions of rabbits (Luzzati et al., 2003; Ponti et al., 2006). Therefore, a $3 \mathrm{D}$ reconstruction was performed through an anterior-posterior portion of the external capsule (Fig. $4 B$; see Materials and Methods) to assess their relationship with the SVZ neurogenic site. The analysis revealed that all clusters appeared as discrete bulks of cells not forming long streams and never contacting the SVZ neurogenic site. To investigate the relationship with surrounding cells (e.g., the occurrence of specific astrocytic arrangements), immunocytochemistry for glial fibrillary astrocytic protein (GFAP) was performed. GFAP staining did not revealed any special density or niche-like organization adjacent to the $\mathrm{DCX}^{+}$cells (Fig. 4D); however, when the $\mathrm{DCX}^{+}$cells were organized to form tightly packed clusters, they occupied glial-empty spaces, the astrocytes being segregated outside of them (Fig. 4D). Quantification of DCX ${ }^{+}$cell clusters (see below and Tables 3, 4, and $5)$ revealed that virtually all of them were contained within the external capsule, mostly residing in its posterior part (Fig. 4B). This analysis further excluded any direct contact between the clusters and the SVZ neurogenic site. Groups of less tightly packed cells and scattered/isolated cells were also observed (Fig. 4C).

\section{Amygdala and claustrum}

Compact cell clusters were rare in the pericapsular gray matter, whereas populations of scattered $\mathrm{DCX}^{+}$cells were prevalent (Fig. 5 ). These cell groups were larger in the amygdala (diameter ranging between 125 and $385 \mu \mathrm{m})$ than in claustrum $(40-200 \mu \mathrm{m})$. Within both regions, large multipolar $\mathrm{DCX}^{+}$neurons endowed with long, dendritic-like processes were mixed with smaller, bipolar cells (Fig. $5 B, C$ ). Bipolar cells represented by far the most 

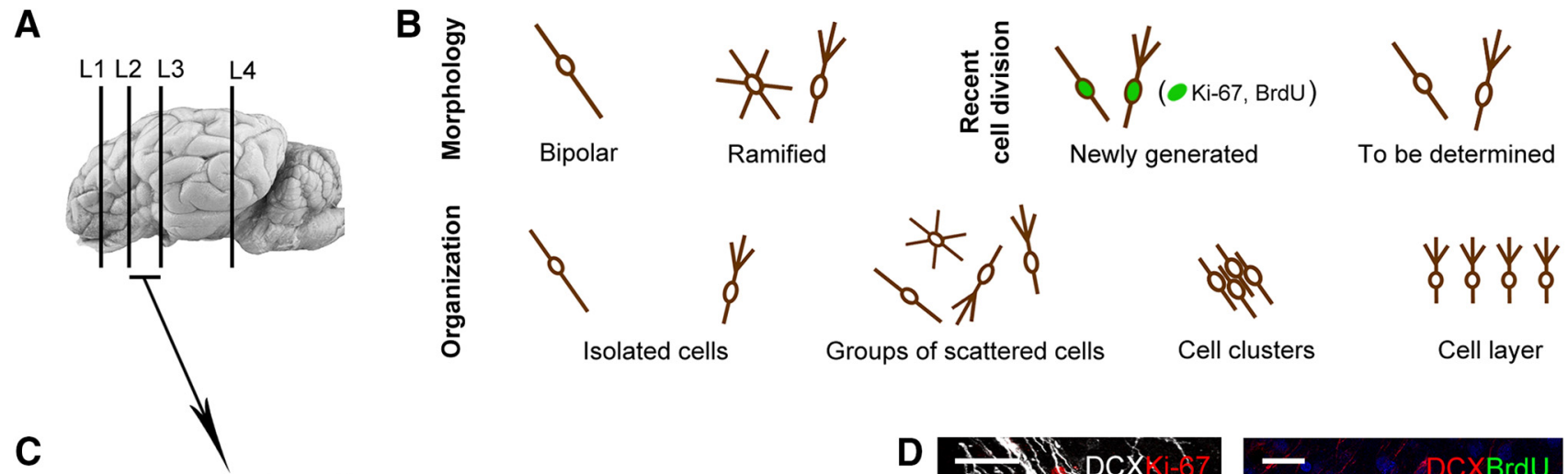

Groups of scattered cells Cell clusters

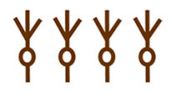

Cell layer
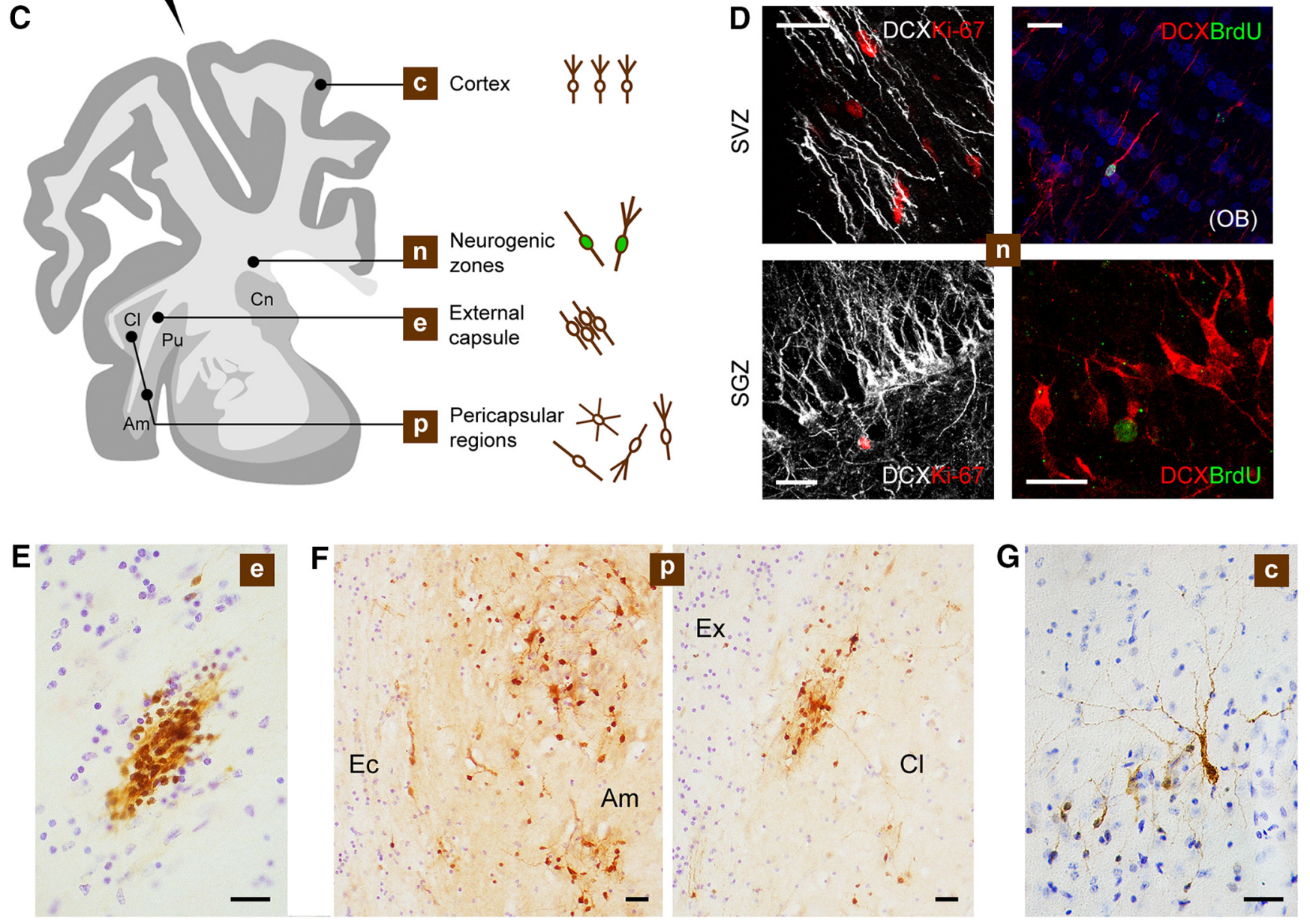

Figure 2. $D C X^{+}$cells in the adult sheep brain. $A, C$, Representative levels of the brain showing different locations of the $D C X^{+}$cells. $B$, Main types of $D C X^{+}$cells encountered in our analysis $\left(D C X^{+}\right.$"objects") classified according to their morphology, spatial organization, and cell division history (newly born vs non-newly generated). $D$, Newly generated neuroblasts in the SVZ and dentate gyrus (SGZ); in both neurogenic sites, $D C X^{+}$cells are intermingled with several nuclei immunoreactive for Ki-67 antigen (rarely double stained in the SVZ due to different expression time course of the markers); BrdU injected $60 \mathrm{~d}$ before the animals were killed is detectable in $D C X^{+}$neuroblasts of the olfactory bulb (OB) and in hippocampal granule cells. $E$ - $G$, Representative photographs of the $D C X^{+}$cells/cell populations at the different locations showed in $C$. $E$, Clusters of $D C X^{+}$cells in the external capsule (Ec). $F$, Scattered $D C X^{+}$cells in the amygdala (Amy) and claustrum (Cl); Ex, capsula extrema. G, Layer II cortical neurons. Scale bars: $30 \mu \mathrm{m} ; \boldsymbol{D}$ (bottom right), $20 \mu \mathrm{m}$.

frequent cell morphology ( $\sim 98-99 \%$; Fig. $5 D)$. Three main cell morphologies were present in the amygdala (Fig. $5 B$ ): type 1 cells (small, bipolar, soma diameter 3-6 $\mu \mathrm{m}$ ), type 2 cells (mediumsized, similar to type 2 a cells in cortex, soma diameter $8-9 \mu \mathrm{m}$ ), and type 3 cells (large, multipolar, soma diameter 9-11 $\mu \mathrm{m}$ ). Two main cell types were detectable in the claustrum (Fig. $5 C$ ): type 1 cells (small, unipolar or bipolar, soma diameter 3-6 $\mu \mathrm{m}$ ) and type 2 cells (soma diameter 7-9 $\mu \mathrm{m}$ ).

\section{$\mathrm{DCX}^{+}$cell populations at different ages}

The same types of analyses performed on the DCX ${ }^{+}$cells in the cortex and capsular and pericapsular regions were performed on early postnatal brains ( $7 \mathrm{~d}$ after birth). Under a qualitative profile, by comparing the occurrence and distribution of $\mathrm{DCX}^{+}$cell populations at different ages, the only substantial difference concerned the presence of cell clusters within the putamen of the newborn and within the corpus callosum of neonatal and prepubertal animals (data not shown), both cell populations then disappearing in adults (La Rosa C., Bonfanti L., unpublished data). All other $\mathrm{DCX}^{+}$cell populations, including cortical immature neurons, neuroblasts of the neurogenic sites, and $\mathrm{DCX}^{+}$cells in capsular/pericapsular regions were present at both ages. However, quantitative evaluations performed in neonates and adults 
A

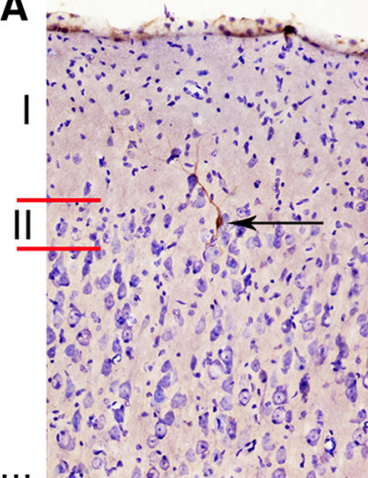

III
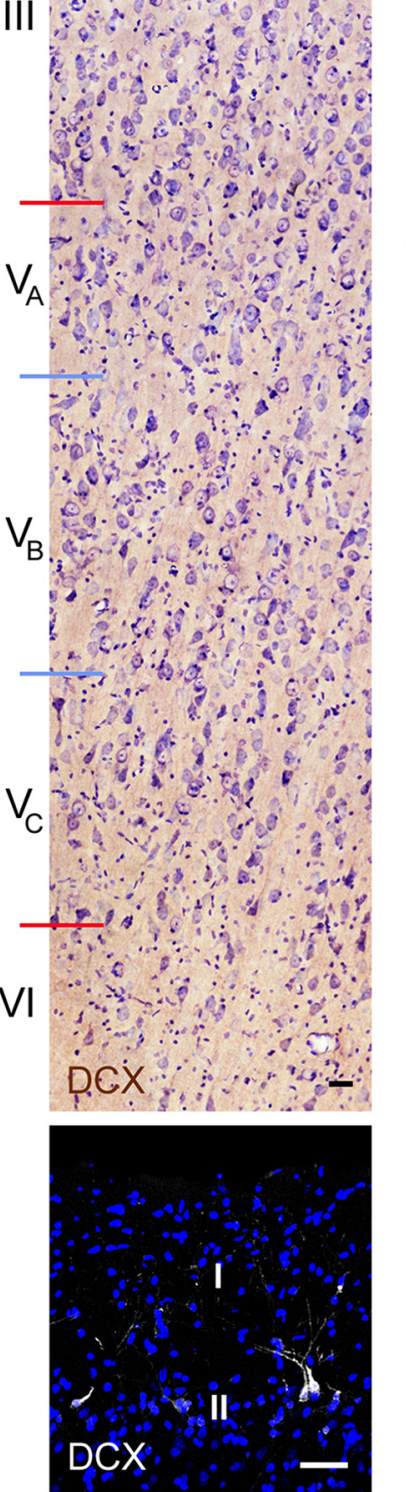

B
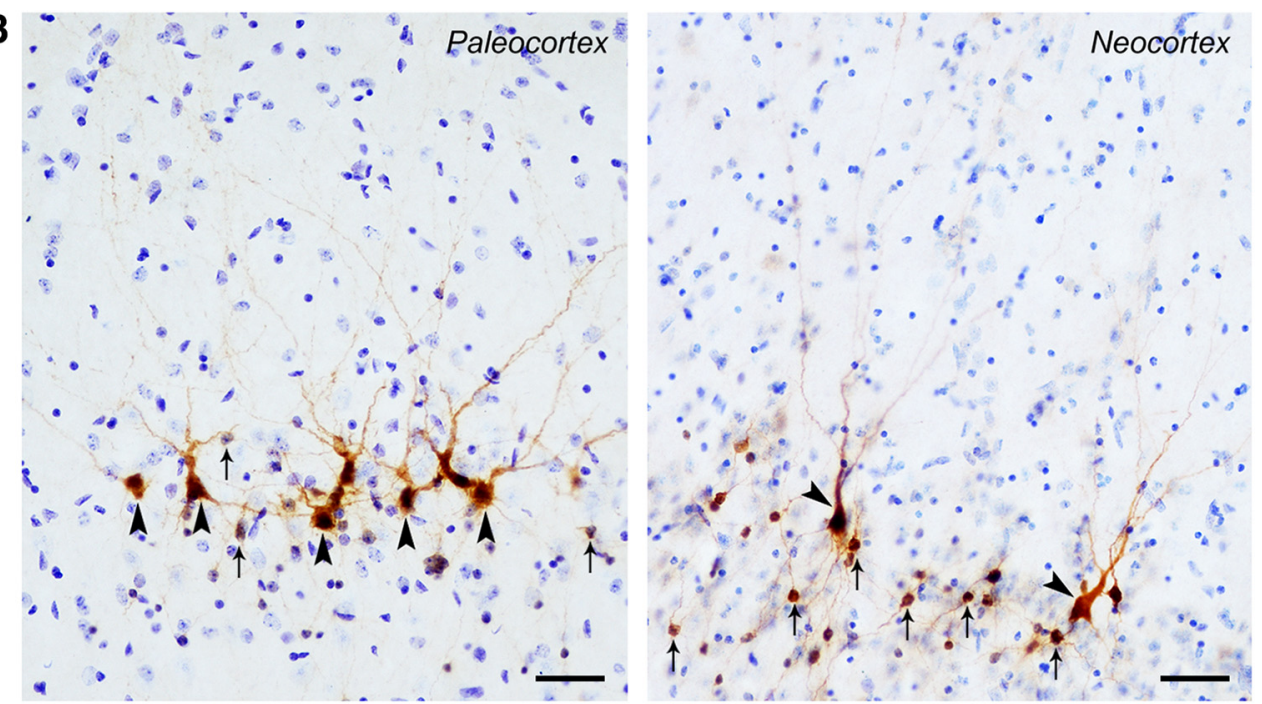

C

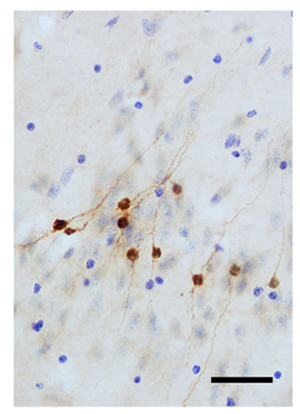

D
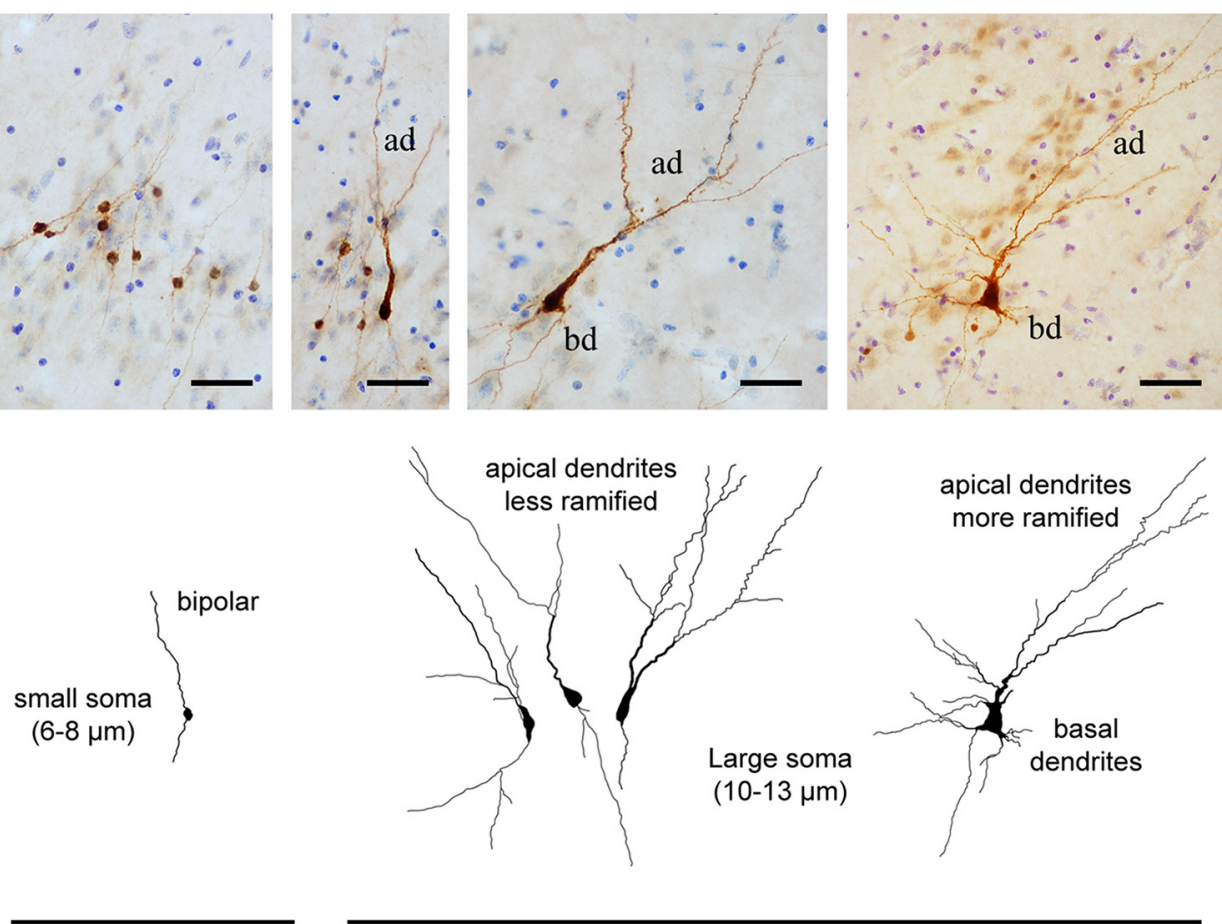

Type 1
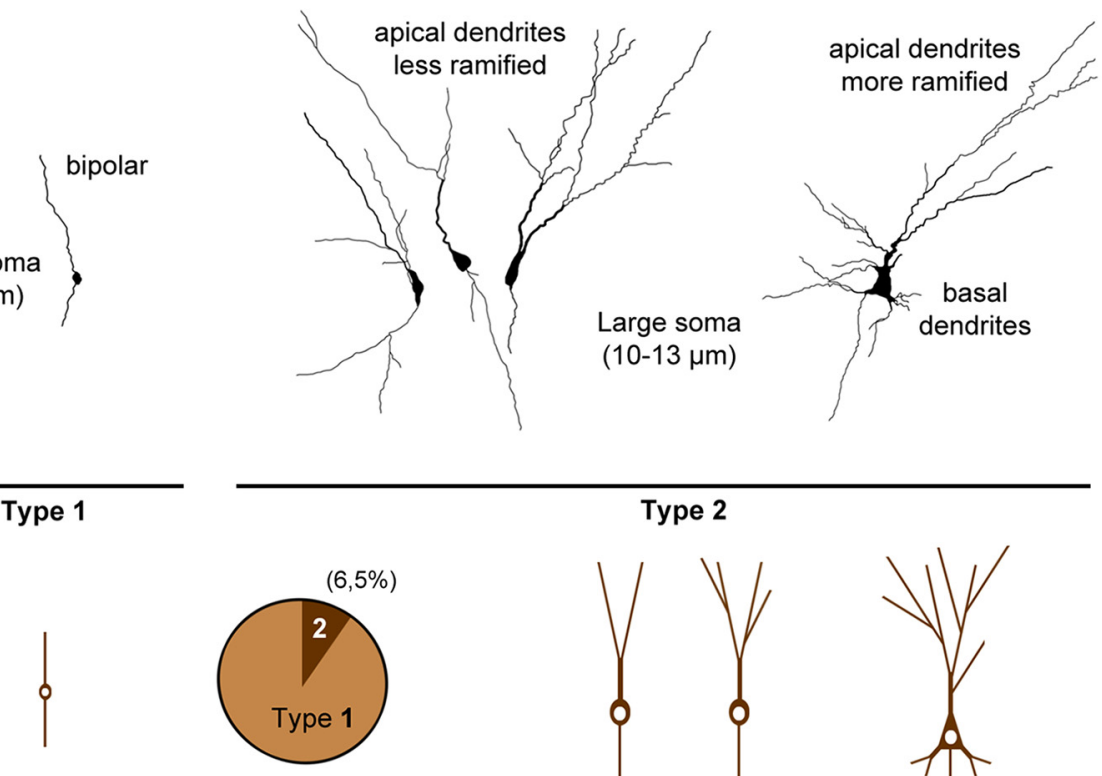

Figure 3. $D C X{ }^{+}$cells in the cerebral cortex of adult sheep. $A$, Location of $D C X{ }^{+}$neurons in the cortical layer II. Top, $D C X$ (brown) and cresyl violet staining. Coronal section cut at the level of the frontal lobe layer IV (inner granular layer) is absent in the agranular isocortex of sheep (Beul and Hilgetag, 2014). WM, White matter. Bottom, Confocal image of the first two cortical layers (DCX, white; DAPI, blue). $\boldsymbol{B}, D C X^{+}$neurons are present both in paleocortex (piriform cortex) and neocortex. Arrows indicate type 1 neurons; arrowheads, type 2 neurons (see $\boldsymbol{D}$ ). $\boldsymbol{C}, \boldsymbol{D}$, Main morphological types of the $D C X^{+}$neurons (neocortex); type 1: small cell body and simpler apical dendritic arborization (ad); type 2: large cell body and more elaborated apical dendritic arborization (type 2a), also including basal dendrites (bd; type $2 \mathrm{~b}$ ); type 2 cells represent $\sim 7 \%$ of total $D C X^{+}$cells. Scale bars, $30 \mu \mathrm{m}$.

revealed differences among these regions (Fig. 6). Compared with newborns, the cerebral cortex of adult animals showed an evident and generalized decrease in the amount of $\mathrm{DCX}^{+}$immature neurons (Fig. $6 A$, top). To quantify this reduction, we calculated the linear density of layer II DCX ${ }^{+}$cells in three cortical segments, including both neocortex and paleocortex of neonatal and adult sheep (see Materials and Methods and Fig. 6A, bottom). In all analyzed regions, both the number and density of $\mathrm{DCX}^{+}$cells underwent an 
A
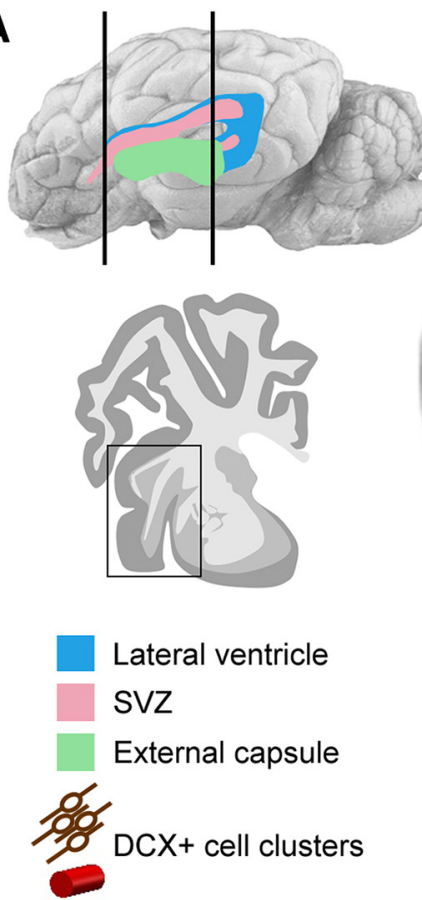

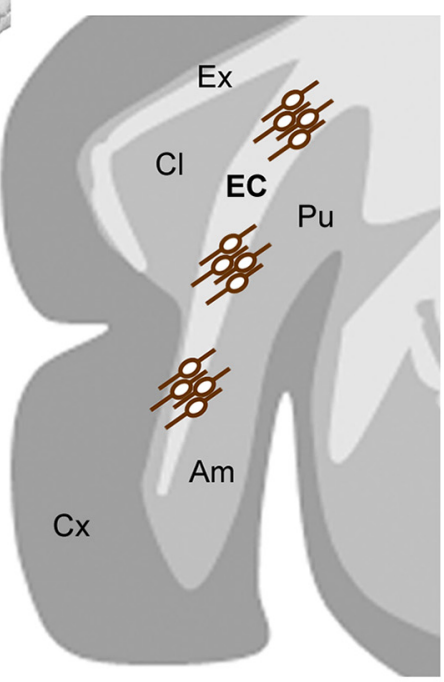

B

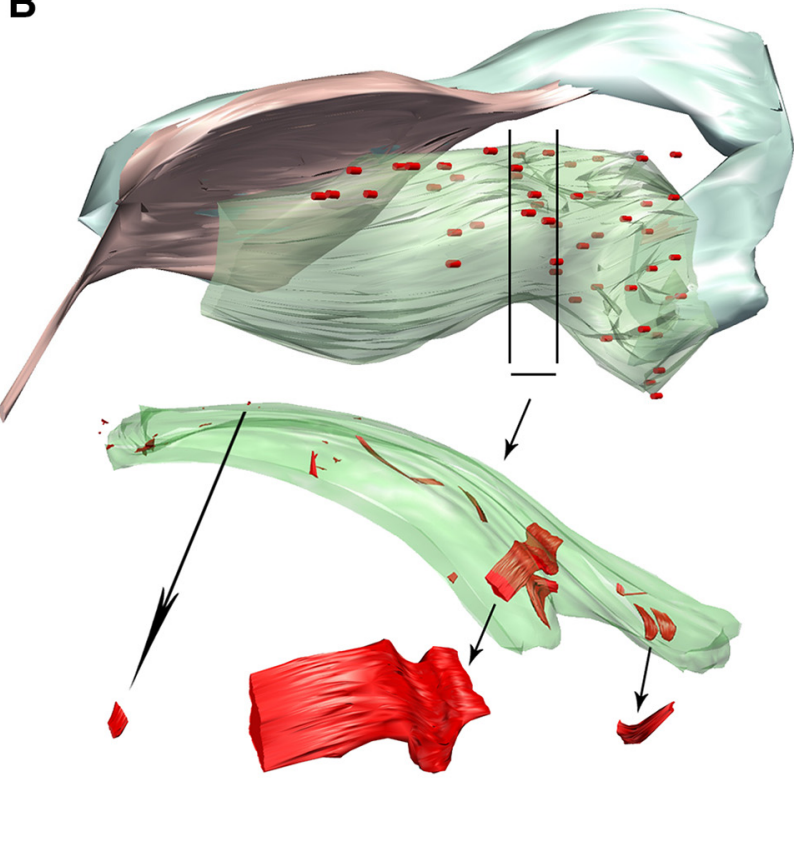

C
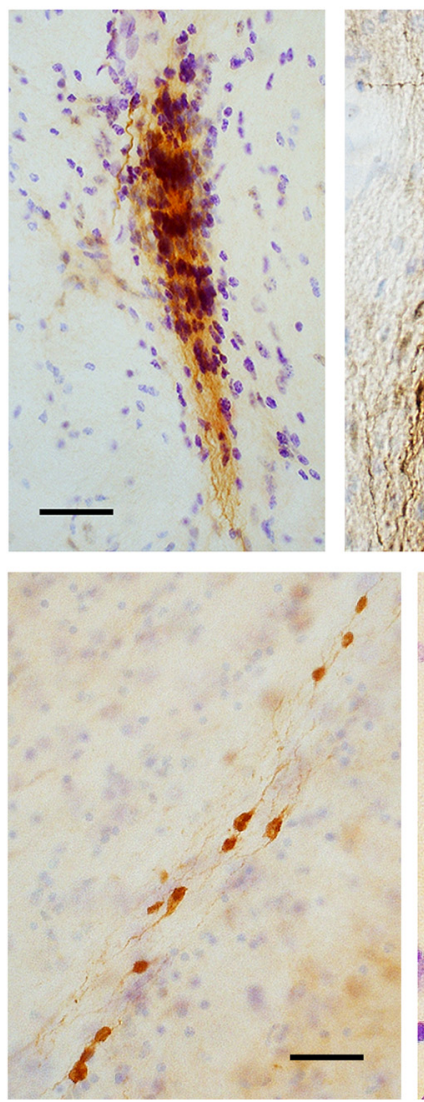
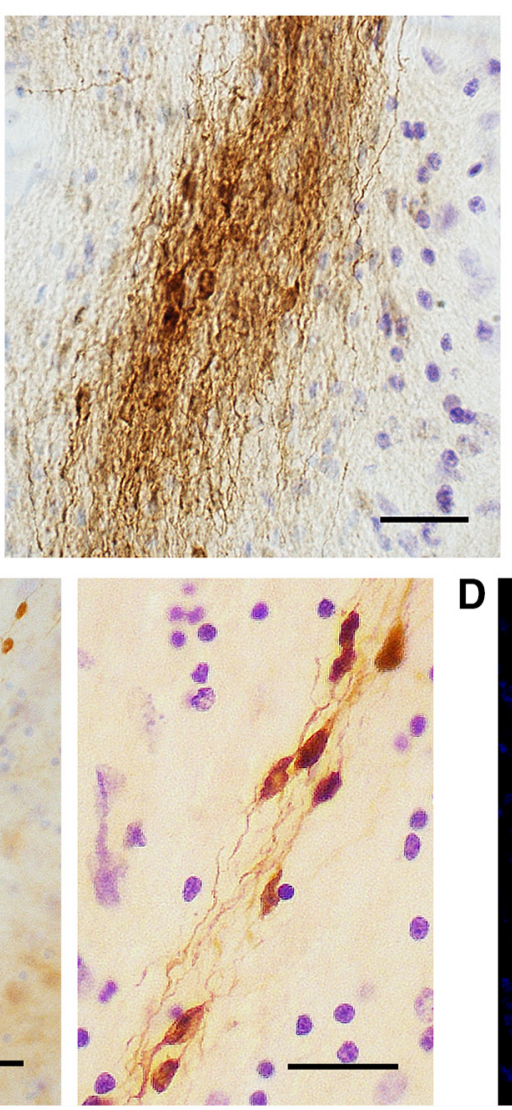

D

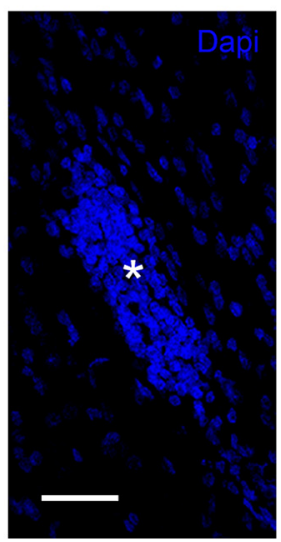

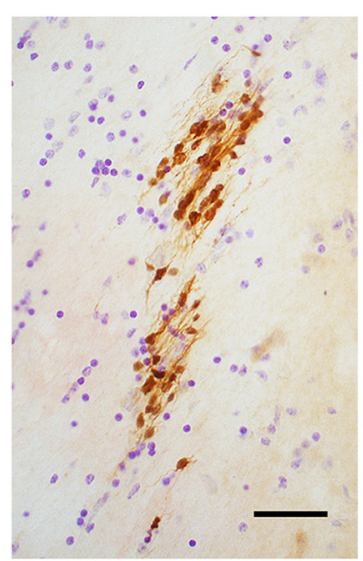
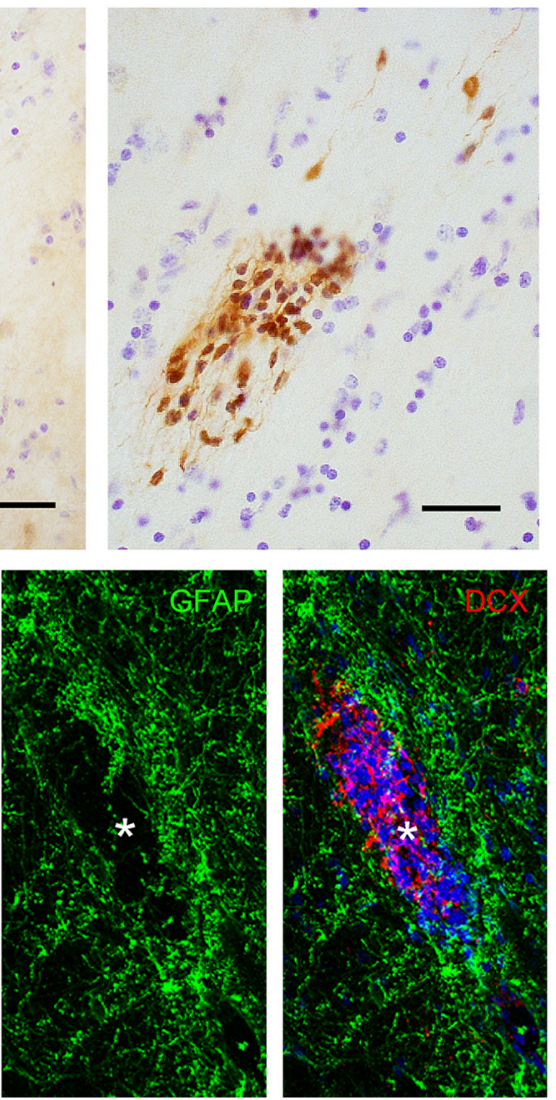

Figure 4. $D C X^{+}$cells in the external capsule of the adult sheep brain. $A, C$, Numerous clusters of tightly packed, $D C X^{+}$cells are present in most of the external capsule (EC).B, Serial reconstruction showing their distribution and size. Ex, Capsula extrema; Am, amygdala; Pu, putamen; $C X$, cerebral cortex. C, Examples of $D C X^{+}$cell clusters showing different types of organization spanning from large, tightly packed cell masses to small groups of dispersed cells. $\boldsymbol{D}$, Cell clusters (red, asterisk) occupy empty spaces within white matter areas devoid of astrocytes (green). Scale bars, $30 \mu \mathrm{m}$.

approximately fourfold reduction with age (see Tables 3, 4, and 5 for statistical comparisons). Such a trend, suggesting an age-related reduction in cortical plasticity of the layer II (as shown previously in several species; Abrous et al., 1997; Varea et al., 2009), parallels the remarkable drop described for the $\mathrm{DCX}^{+}$cell populations in the neurogenic sites of different mammals (Sanai et al., 2011; Lipp and Bonfanti, 2016), which is also strikingly evident in both SVZ and hippocampus of sheep (Fig. 6B). 
Table 3. Quantification of $D C X^{+}$clusters/cells in the capsular/pericapsular and cortical regions of neonatal and adult sheep brains

\begin{tabular}{|c|c|c|c|c|c|c|}
\hline & \multicolumn{3}{|l|}{ Newborn } & \multicolumn{3}{|l|}{ Adult } \\
\hline & Area $\left(\mathrm{mm}^{2}\right)$ & No. of cells & $\begin{array}{l}\text { Density } \\
\left(D C X^{+} \text {objects } / \mathrm{mm}^{2}\right)\end{array}$ & Area $\left(\mathrm{mm}^{2}\right)$ & No. of cells & $\begin{array}{l}\text { Density } \\
\left(D C X^{+} \text {objects } / \mathrm{mm}^{2}\right)\end{array}$ \\
\hline External capsule & $1.72 \pm 0.3$ & $34 \pm 4^{a}$ & $19.97 \pm 1.4$ & $4.28 \pm 0.3$ & $39 \pm 7^{a}$ & $9.21 \pm 1.6$ \\
\hline Claustrum & $7.52 \pm 0.7$ & $75 \pm 22$ & $9.78 \pm 2.1$ & $12.56 \pm 1.2$ & $77 \pm 62$ & $5.86 \pm 4.3$ \\
\hline \multirow[t]{2}{*}{ Amygdala } & $11.44 \pm 1.0$ & $209 \pm 75$ & $18.44 \pm 6.9$ & $18.33 \pm 3.5$ & $252 \pm 18$ & $14.02 \pm 2.1$ \\
\hline & Length (mm) & No. of cells & Linear density (cells/mm) & Length (mm) & No. of cells & Linear density (cells/mm) \\
\hline Neocortex & $7.20 \pm 0.4$ & $329 \pm 4$ & $45.69 \pm 2.6$ & $9.47 \pm 2.4$ & $62 \pm 15$ & $6.54 \pm 0.5$ \\
\hline Paleocortex & $4.46 \pm 0.3$ & $371 \pm 11$ & $83.41 \pm 2.3$ & $5.53 \pm 0.8$ & $164 \pm 68$ & $29.65 \pm 7.2$ \\
\hline
\end{tabular}

${ }^{a} \mathrm{DCX}{ }^{+}$objects.

Table 4. Two-way ANOVA for all brain regions and $t$ test for each region comparing newborn and adult values of perimeter/area and number and density of $D C X^{+}$ cells

\begin{tabular}{lccc}
\hline & \multicolumn{2}{l}{ Newborns vs adults } & \\
\cline { 2 - 4 } & Area $\left(\mathrm{mm}^{2}\right)$ & No. of cells & Density \\
\hline Two-way ANOVA & $F=5.389 ;$ & $F=136.551 ;$ & $F=84.258 ;$ \\
& $p=0.003^{*}$ & $p<0.0001^{*}$ & $p<0.0001^{*}$ \\
External capsule & $<0.0001^{*}$ & $0.300^{* *}$ & $0.001^{*}$ \\
Claustrum & $0.003^{*}$ & $0.961^{* *}$ & $0.231^{* *}$ \\
Amygdala & $0.030^{*}$ & $0.422^{* *}$ & $0.347^{* *}$ \\
& & & Linear density \\
& No. of cells & Length $(\mathrm{mm})$ & $($ cells $/ \mathrm{mm})$ \\
\hline Neocortex & $<0.0001^{*}$ & $<0.0001^{*}$ & $<0.0001^{*}$ \\
Paleocortex & $0.164^{* *}$ & $0.001^{*}$ & $<0.0001^{*}$ \\
\hline
\end{tabular}

Numbers indicate $p$ values. ${ }^{*} p<0.05 ;{ }^{* *} p>0.05$.

Table 5. Pairwise two-way ANOVA analyses of the density and number of $D C X^{+}$ cells/objects in different brain regions between newborn and adult animals

\begin{tabular}{|c|c|c|c|c|c|}
\hline & Amygdala & Claustrum & $\begin{array}{l}\text { External } \\
\text { capsule }^{a}\end{array}$ & Paleocortex & Neocortex \\
\hline \multicolumn{6}{|l|}{ No. of cells/objects } \\
\hline Amygdala & & $0.535^{* *}$ & $0.463^{* *}$ & $<0.0001^{*}$ & $<0.0001^{*}$ \\
\hline Claustrum & $0.535^{* *}$ & & $0.933^{* *}$ & $<0.0001^{*}$ & $<0.0001^{*}$ \\
\hline External capsule $^{a}$ & $0.463^{* *}$ & $0.933^{* *}$ & & $<0.0001^{*}$ & $<0.0001^{*}$ \\
\hline Paleocortex & $<0.0001^{*}$ & $<0.0001^{*}$ & $<0.0001^{*}$ & & $<0.0001^{*}$ \\
\hline Neocortex & $<0.0001^{*}$ & $<0.0001^{*}$ & $<0.0001^{*}$ & $<0.0001^{*}$ & \\
\hline \multicolumn{6}{|l|}{ Density } \\
\hline Amygdala & & $0.923^{* *}$ & $0.181^{* *}$ & $<0.0001^{*}$ & $<0.0001^{*}$ \\
\hline Claustrum & $0.923^{* *}$ & & $0.055^{* * *}$ & $<0.0001^{*}$ & $<0.0001^{*}$ \\
\hline External capsule $^{a}$ & $0.181^{* *}$ & $0.055^{* * *}$ & & $<0.0001^{*}$ & $<0.0001^{*}$ \\
\hline Paleocortex & $<0.0001^{*}$ & $<0.0001^{*}$ & $<0.0001^{*}$ & & $<0.0001^{*}$ \\
\hline Neocortex & $<0.0001^{*}$ & $<0.0001^{*}$ & $<0.0001^{*}$ & $<0.0001^{*}$ & \\
\hline
\end{tabular}

This analysis compares age-related changes between pairs of brain regions indicated in the first row and column. Numbers indicate $p$-values for the interaction between age and brain region. * Significant interaction; ** ${ }^{*}$ nonsignificant interaction; ${ }^{* *}$ close to critical value of $p=0.05$.

${ }^{a} \mathrm{DCX}{ }^{+}$objects.

Interestingly enough, in contrast to their neocortical counterparts, both the number and the density of $\mathrm{DCX}^{+}$cell populations in the capsular and pericapsular regions were stable at both ages (for statistics, see Fig. 6C and Tables 3, 4, and 5). The slight reduction in the density of $\mathrm{DCX}^{+}$cell clusters detectable in the external capsule is related to the relative increase in the area of this region with respect to others (increasing volume of the capsule itself; see Tables 3, 4, and 5). Two-way ANOVA analyses confirmed the presence of a significant interaction between brain region and age for both number $(F=$ $136,551 ; p<0.0001)$ and density of $(F=84,258$; $p<0.0001) \mathrm{DCX}^{+}$ cells/objects. Pairwise comparisons clearly showed that subcortical regions had a similar age related trend that differed from that of both paleo and neocortex (Tables 3, 4, and 5). As to the topographical localization of the $\mathrm{DCX}^{+}$objects within each brain region, these structures were located more posteriorly in the adult external capsule, whereas in the newborn, they were distributed homogeneously along the entire anteroposterior axis. In claustrum and amygdala, the distribution was generally homogeneous (mainly located in the basolateral nucleus in the latter).

\section{Cell proliferation analysis}

The heavy occurrence of $\mathrm{DCX}^{+}$cells in the cerebral cortex, external capsule, and surrounding regions of the sheep brain raises the question of whether they are newly generated. Analysis with Ki-67 antigen and BrdU in adults consistently revealed immunopositive nuclei in both SVZ and hippocampal neurogenic sites, here used as internal controls for the detection of cell proliferation markers and neurogenesis (Fig. 2). In contrast, no Ki-67/ DCX colocalization was detectable in any of the cortical or capsular/pericapsular regions analyzed (Fig. 7A) and no BrdU staining was found in association with parenchymal $\mathrm{DCX}^{+}$cells in any of the adult animals injected with the exogenous cell proliferation marker and subsequently analyzed at 30,60, and $120 \mathrm{~d}$ survival (Fig. 7A). The results obtained by joining local cell proliferation marker and BrdU pulse-labeling analyses strongly indicate that the external capsule/pericapsular $\mathrm{DCX}^{+}$cells do not divide at any of the adult ages considered, thus excluding the occurrence of parenchymal neurogenesis.

To confirm that these cell populations were generated earlier, during embryogenesis, DCX/BrdU double staining was performed in lambs born from mothers injected with BrdU 3 months before parturition (Fig. 7B). Numerous $\mathrm{BrdU}^{+}$nuclei were present consistently in all areas analyzed. In the external capsule of neonates, some of them were detectable in $\mathrm{DCX}^{+}$cells of the tightly packed clusters as well as in isolated cells (Fig. 7B). Some $\mathrm{BrdU}^{+}$cells were $\mathrm{DCX}^{-}$, likely corresponding to postmitotic (mature) neurons that had been generated during embryogenesis and had already lost their DCX staining (see below). DCX ${ }^{+}$cells not immunoreactive for BrdU were also present, indicating immature cells generated at previous or later developmental stages. After analysis with $\mathrm{Ki}-67$ antigen in neonates, some scattered immunopositive nuclei were detectable at different locations of the brain parenchyma, yet never after double staining with $\mathrm{DCX}^{+}$cells (Fig. $7 B$ ), thus indicating that these latter are no more proliferating after birth. A similar pattern was observed in the cortex, where no $\mathrm{Ki}-67^{+} / \mathrm{DCX}^{+}$or BrdU/DCX ${ }^{+}$cells were detectable in the adult. Whereas $\mathrm{BrdU}^{+} / \mathrm{DCX}^{+}$cells were detected systematically in cortical layer II of neonates, these cells were far more abundant in the neocortex with respect to the paleocortex (see pie charts in Fig. $7 B$ ). Similarly to what was observed in capsular/ pericapsular regions, some $\mathrm{Ki}-67^{+}$nuclei were present in the cortex of neonates but never after double staining with DCX. 
A
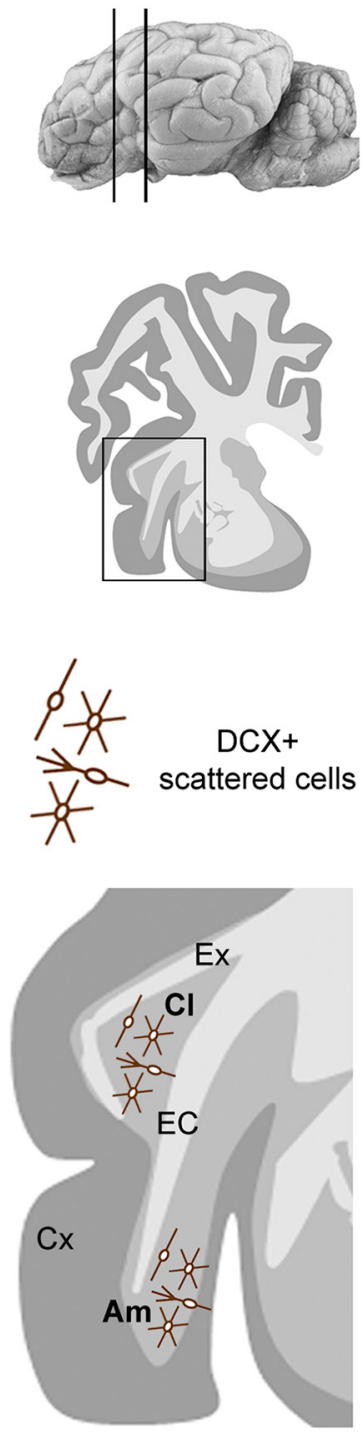

D

$(2,2 \%)(1,3 \%)$

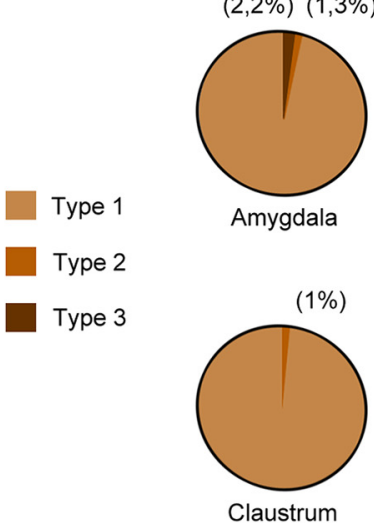

B

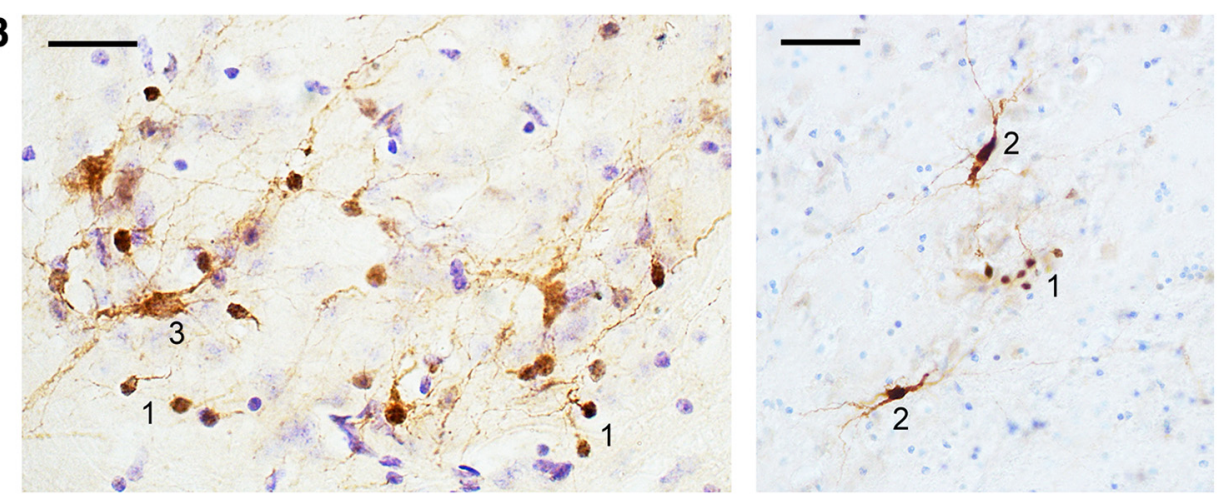

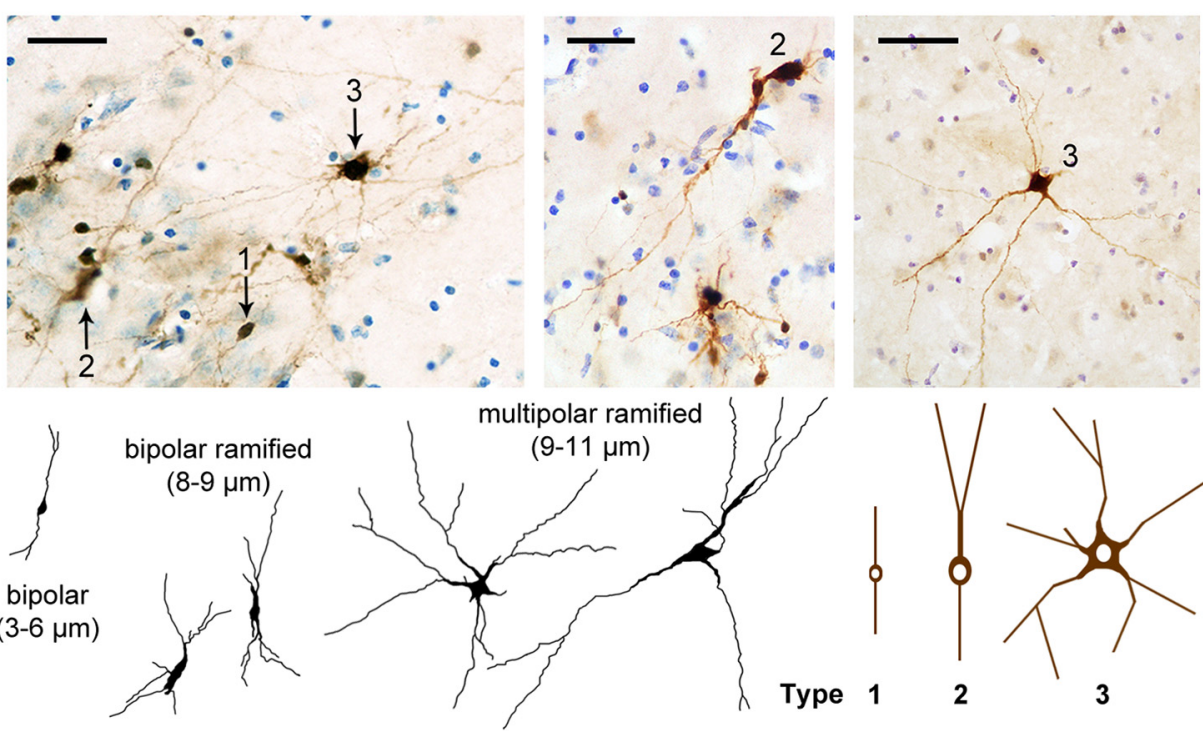

C
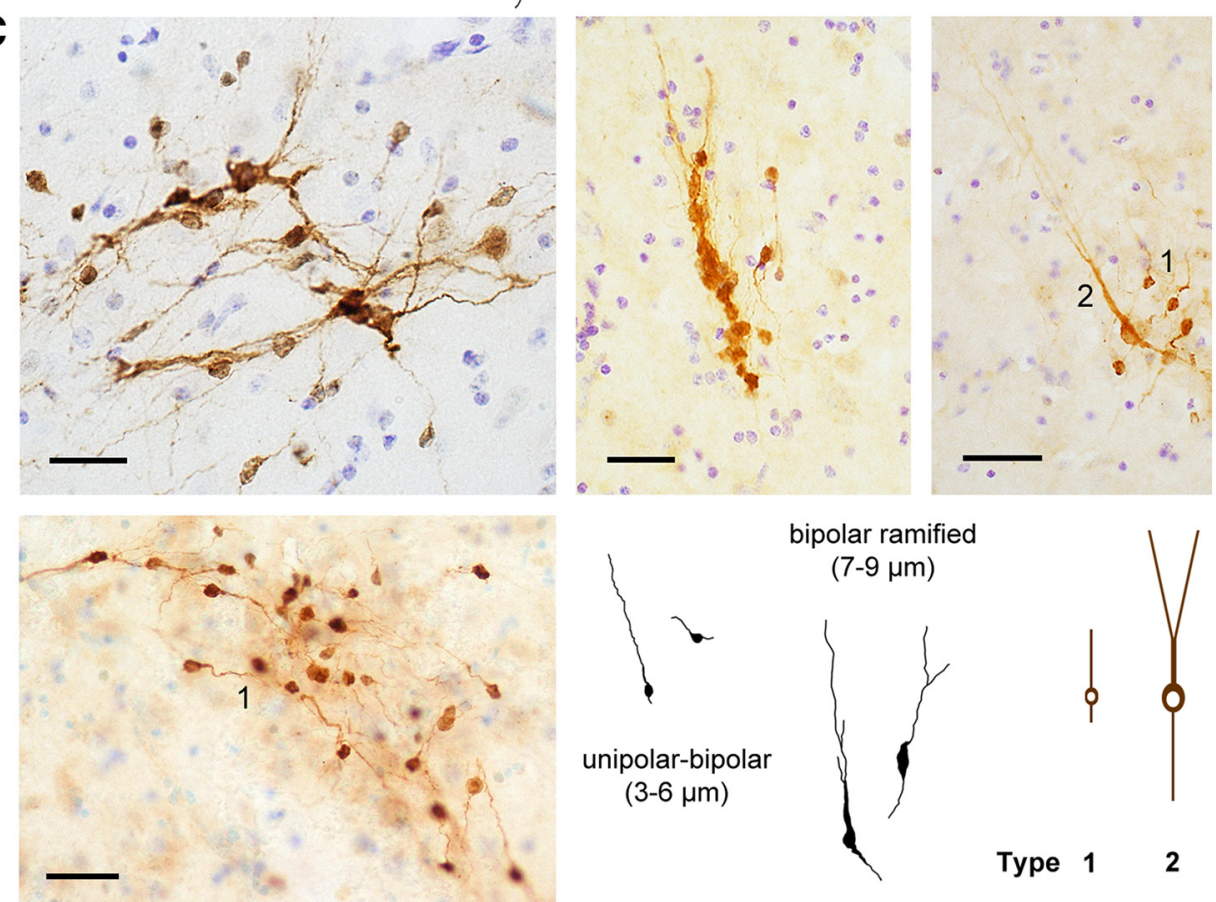

Figure 5. $D C X^{+}$cells in the pericapsular regions of the adult sheep brain. EC, External capsule; Ex, capsula extrema; $C X$, cerebral cortex. $A$, Groups of scattered, $D C X^{+}$cells are present within the amygdala (Am; images in $\boldsymbol{B}$ ) and claustrum ( $\left(\mathrm{l}\right.$, images in $\boldsymbol{C}$ ). The morphology of the $\mathrm{DCX}{ }^{+}$spans from small bipolar to large multipolar in the amygdala $(\boldsymbol{B}$, bottom; in black, real drawing of some cells; in brown, main cell types); it appears simpler in the claustrum, in which most cells are small unipolar/bipolar and some show simple ramifications ( $\boldsymbol{C}$, bottom right). $\boldsymbol{D}$, Quantification of the relative amount of different cell types. Scale bars, $30 \mu \mathrm{m}$. 

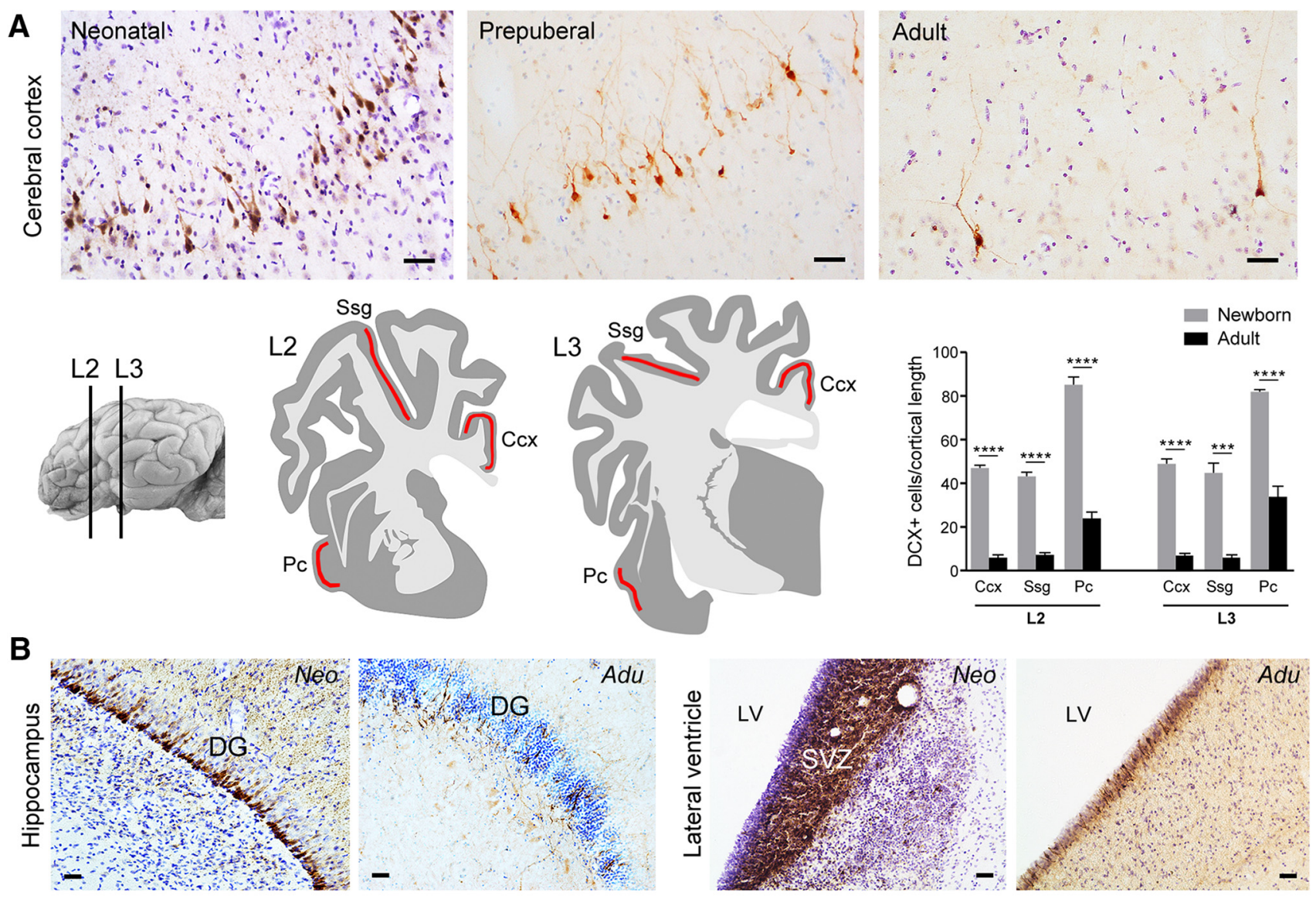

C
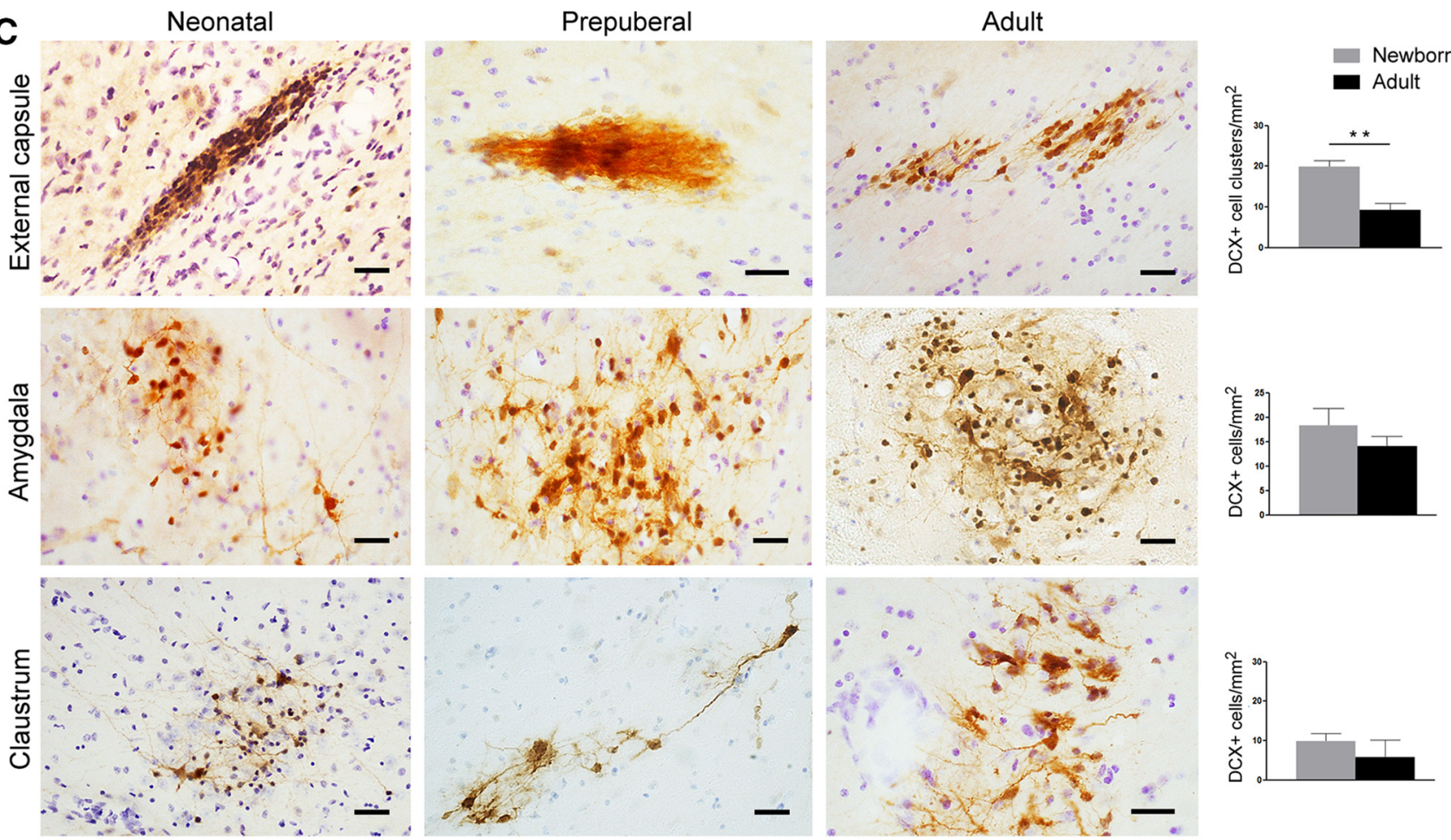

Figure 6. $D C X^{+}$cells in the sheep brain at different ages. $A$, Evident reduction of the amount of $D C X^{+}$neurons in the cortical layer II with increasing age is clearly visible after qualitative analysis (top). Quantitative evaluation of $D C X^{+}$cell linear density (number of $D C X^{+}$neurons in layer II/cortical tract length; bottom) in three cortical regions (red areas) at two brain levels of the newborn and adult sheep. PC, Piriform cortex; Ssg, suprasylvian gyrus; $C\left(x\right.$, cingulate cortex $\left({ }^{* * *} p=0,0001,{ }^{* * *} p<0,0001\right) . B$, Striking reduction of $D C X^{+}$cell populations is clearly evident in the dentate gyrus (DG; note the dilution of the $D C X^{+}$cell layer) and SVZ (note the reduction in thickness of the $D C X^{+}$germinal layer) neurogenic sites of neonatal and adult sheep. $C$, 0 ccurrence, morphology, distribution, and amount (quantifications on the right; see also Tables $3,4,5$ ) of $\mathrm{DCX}{ }^{+}$cells in the sheep capsular/pericapsular regions do not vary significantly at different ages (apart from a slight reduction observed in the external capsule; see text). Scale bars, $30 \mu \mathrm{m}\left({ }^{* *} p=0,001\right)$. 
A
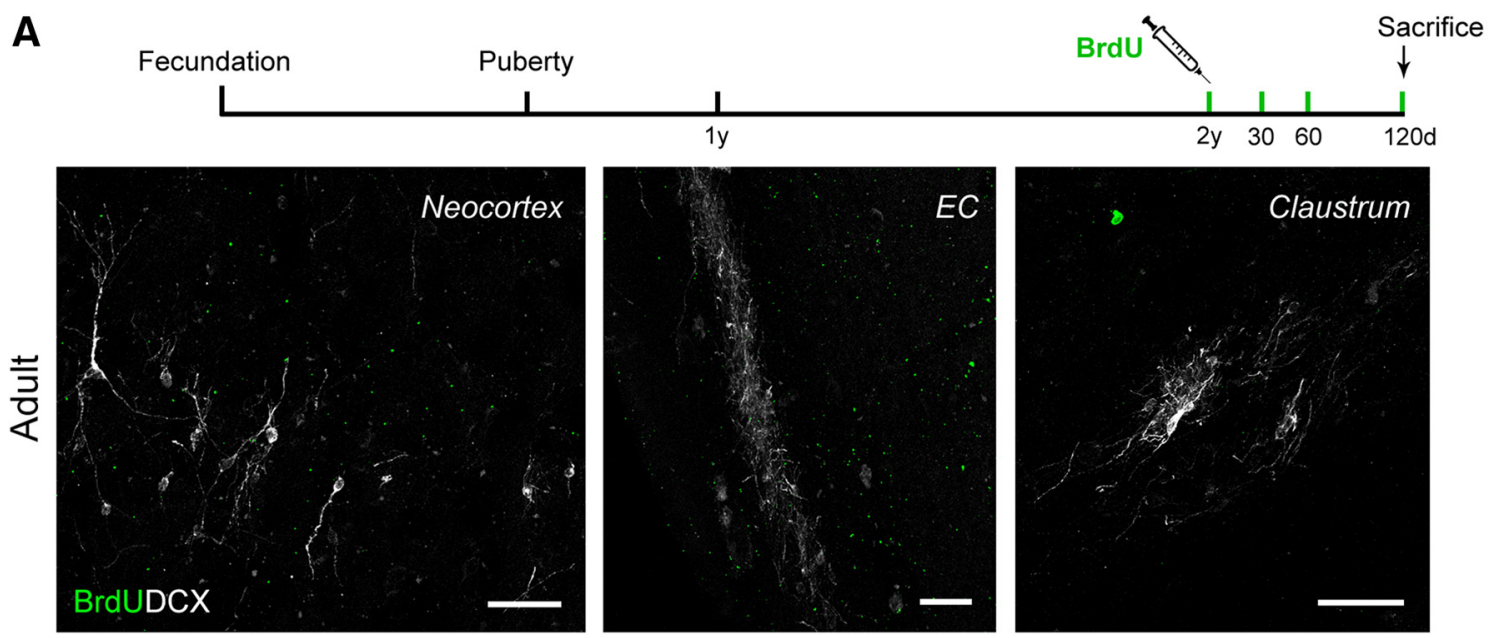

DCX+/Ki-67+

$\mathrm{DCX}+/ \mathrm{BrdU}+$

$\square \mathrm{DCX}+$

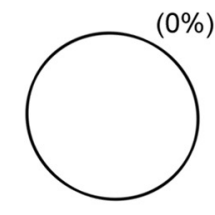

B
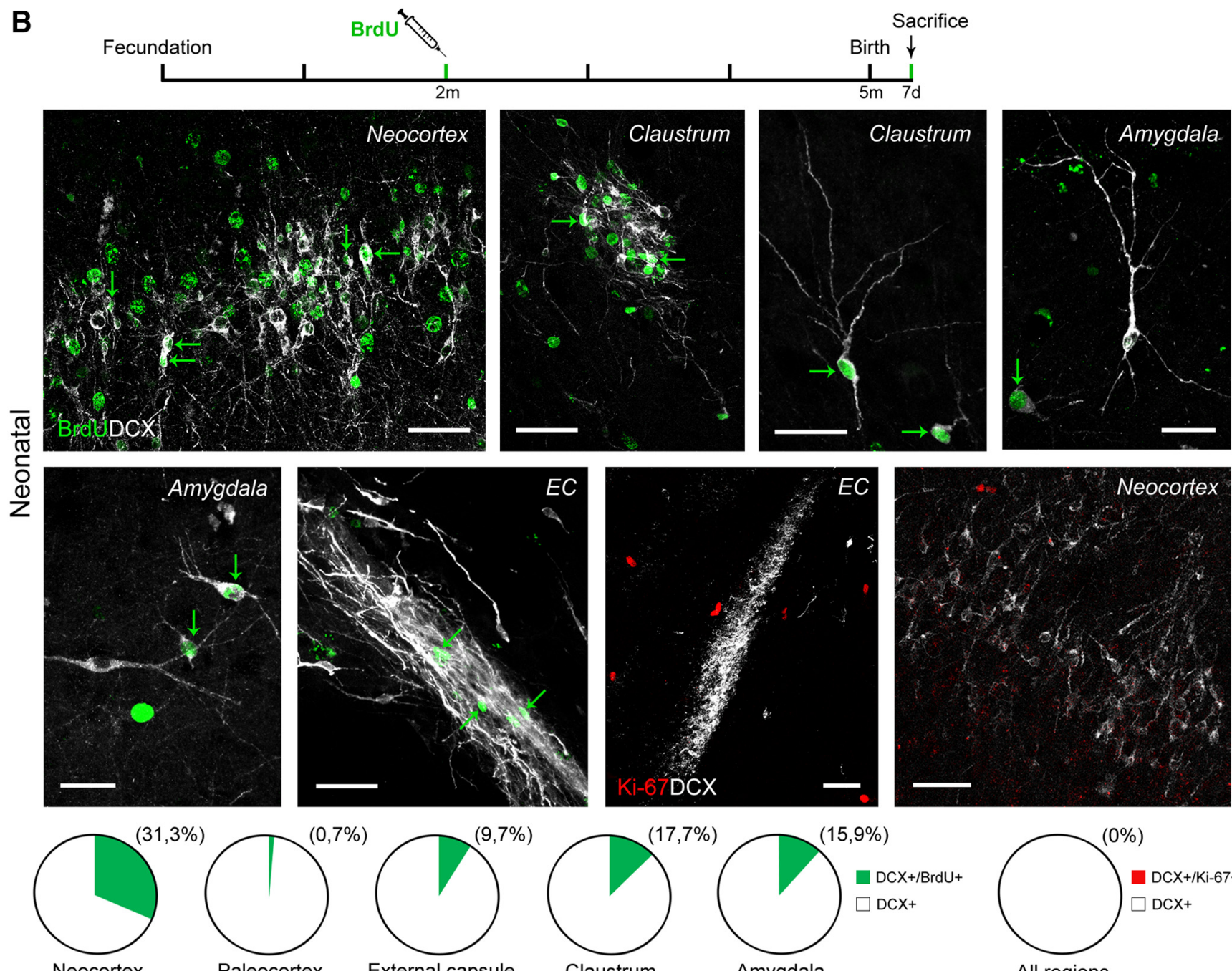

Paleocortex
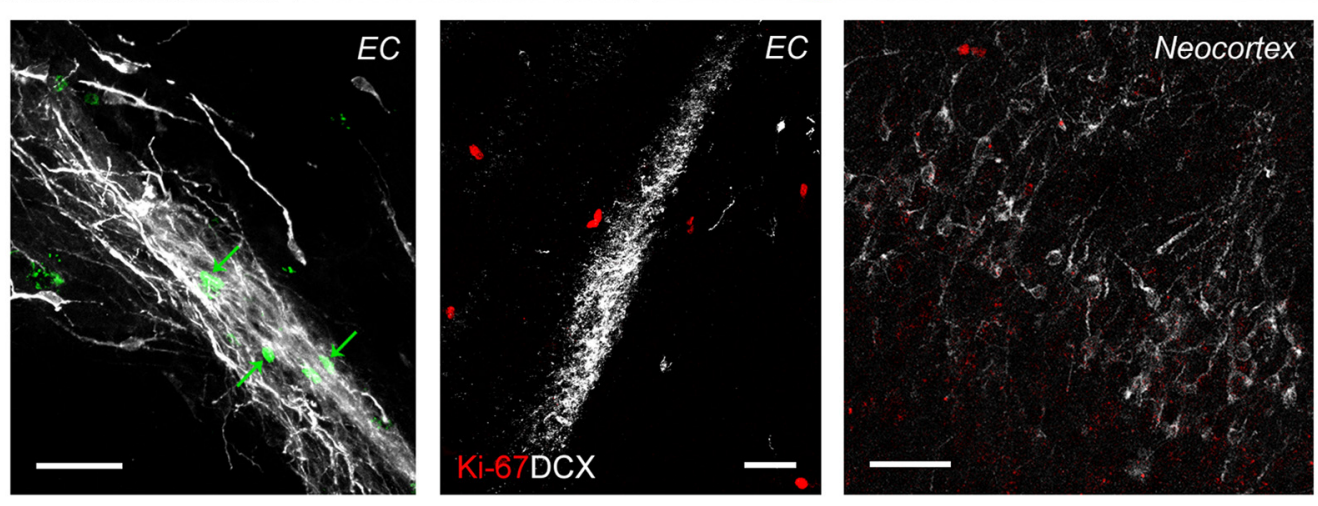

Neocortex
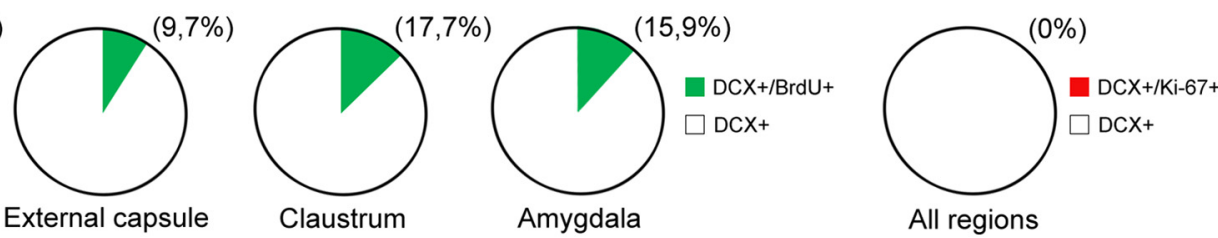

Figure 7. $D C X^{+}$cells in cortical layer II, external capsule, and pericapsular regions of the adult sheep are non-newly generated. $A$, Double staining with cell proliferation markers and DCX in the brain parenchyma of the adult sheep: no double-stained cells were found in any of the regions investigated (same results with Ki-67 antigen; images not shown). $\boldsymbol{B}$, BrdU and Ki-67 antigen double staining with DCX in different brain regions of the neonatal brain (after BrdU treatment of the ewes at the second month of pregnancy). Quantification of DCX ${ }^{+} / \mathrm{BrdU}^{+}$cells in neonatal lambs are represented in pie charts: populations of embryonically generated cells are detectable both in cortex and in capsular/pericapsular regions. Scale bars, $30 \mu \mathrm{m}$.

Cell maturity/immaturity and pallial/subpallial origin markers

To get some insight concerning the degree of maturation of the $\mathrm{DCX}^{+}$cell populations described here, we used markers com- monly used to assess their neuronal maturational stage. We analyzed NeuN, an RNA-binding protein expressed by most postmitotic neurons that start differentiation (Mullen et al., 1992; Fig. 8A). Only a small percentage of the $\mathrm{DCX}^{+}$cells 

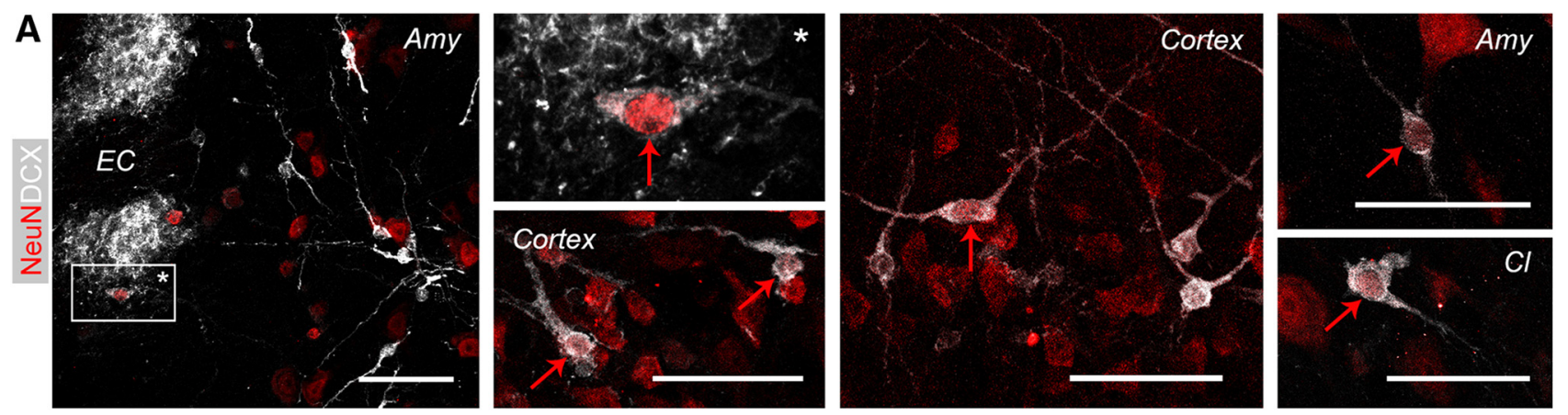

B

NeuN<smiles>[R]OC(C)(C)OC</smiles><smiles>[2H][14C](=[14N][Na])OC(C)(C)C</smiles>
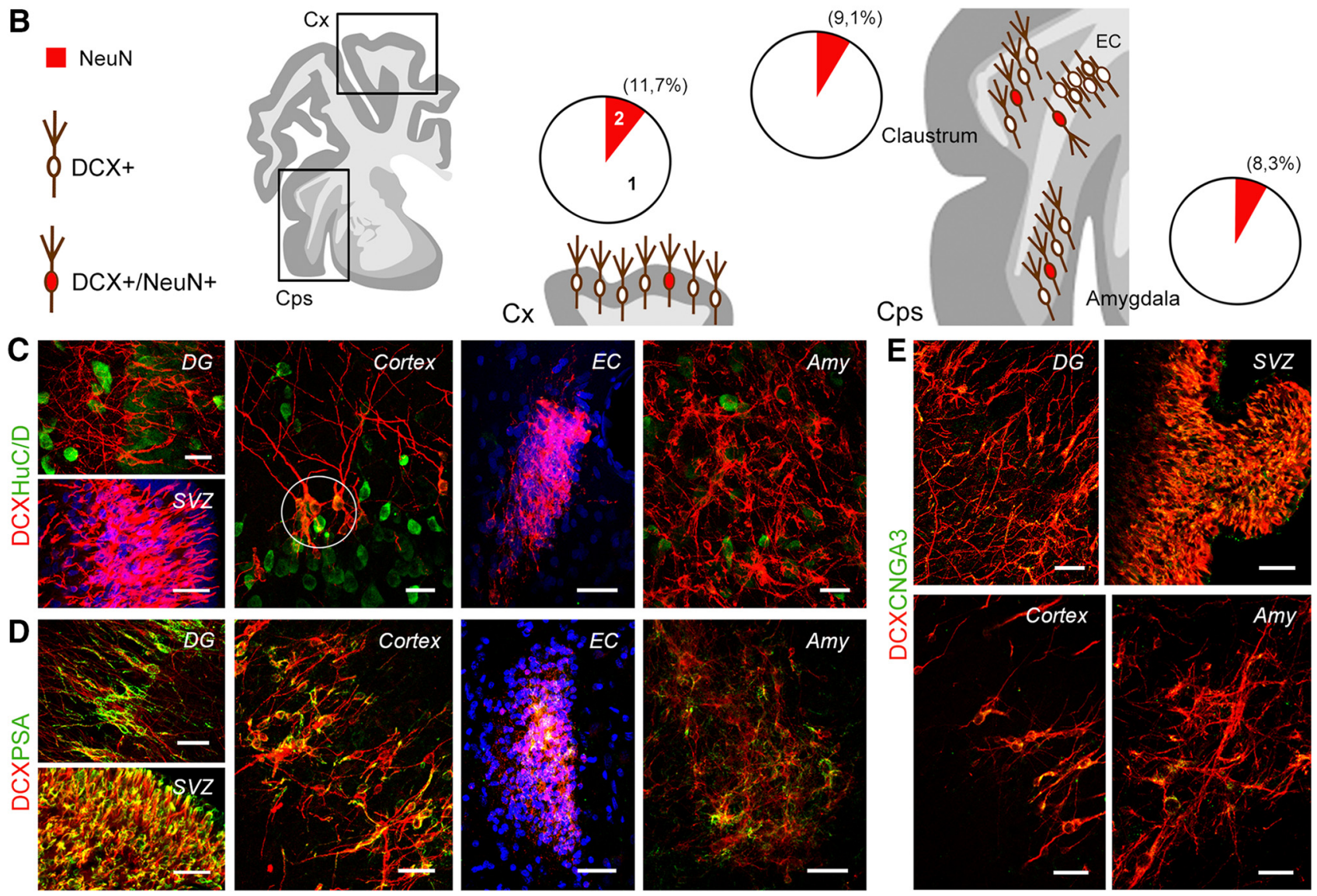

$\mathbf{F}$

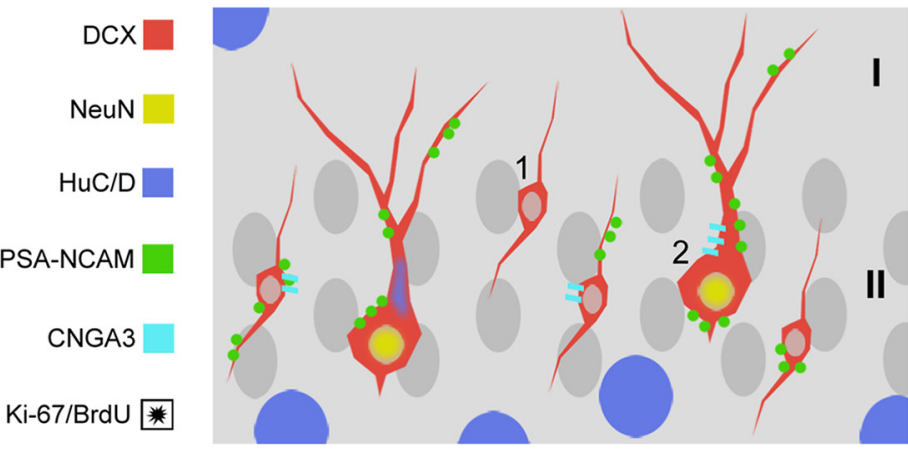

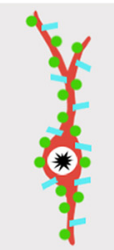
Newlyborn
Classic neurogenic sites

Neurogenic

Structural plasticity

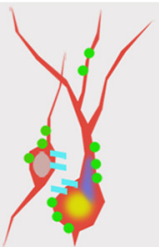

Immature

Cortex layer II Amygdala, Claustrum External capsule

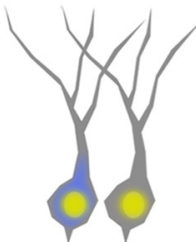

Mature

The remaining brain parenchyma

Figure 8. Markers of neuronal maturity/immaturity in $D C X^{+}$cells of the adult $(A, B, D)$ and young $(C, E)$ sheep brain. $A$, Double staining for $D C X$ and NeuN (red arrows) in different brain regions. EC, External capsule; Amy, amygdala; $\mathrm{Cl}$, claustrum. B, Both in cortical (CX) and in capsular/pericapsular regions (Cps), the $D C X^{+} / \mathrm{NeuN}^{+}$cells represent a small subpopulation of all DCX ${ }^{+}$cells (red areas in pie charts); 1 and 2 in cortex pie chart refer to type 1/type 2 cells (Fig. 2). C, Marker of initial differentiation and maturity HuC/D is not detectable in the neurogenic sites (DG, dentate gyrus; SVZ, subventricular zone) and mostly absent in DCX ${ }^{+}$immature neurons apart from a weak expression in some type 2 cells of the cortical layer II (circle). D, Double staining with the marker of immaturity PSA-NCAM reveals all DCX ${ }^{+}$cells largely decorated in the neurogenic zones (DG and SVZ), whereas only subpopulations of DCX ${ }^{+}$cells are partially stained in the cortical and subcortical regions. $\boldsymbol{E}$, Similarly to PSA-NCAM, the A3 subunit of the cyclic nucleotide-gated ion channel (CNGA3) is detectable in most $D C X^{+}$cells of the neurogenic sites and in subpopulations of $D C X^{+}$cells in other brain regions. $\boldsymbol{F}$, Schematic summary of maturity/immaturity features in $D C X^{+}$cells of the sheep as revealed by different cellular markers (showed for the cortex but representative of all regions investigated). Scale bars, $30 \mu \mathrm{m}$. 
$(\sim 10 \%)$ coexpressed $\mathrm{NeuN}$ in different regions $(11.7 \%$ in cortical layer II; 9.1\% in claustrum; $8.3 \%$ in amygdala; Fig. $8 B$ ). In the cortex, all the $\mathrm{DCX}^{+} / \mathrm{NeuN}^{+}$neurons fell in the type 2 cell morphology with ramified dendrites. In the external capsule, NeuN was not detectable within the tightly packed cell clusters, whereas some isolated cells detached from the clusters were double stained (Fig. 8A). This gives support to the hypothesis that larger $\mathrm{DCX}^{+}$cells in layer II are slightly more mature than small cells, showing increases in NeuN expression as described during neuronal differentiation in the adult dentate gyrus (Kempermann et al., 2004; Marqués-Marí et al., 2007). Similarly, another marker of mature neuronal cells (HuC/D RNA-binding protein; Barami et al., 1995) was detected only in some of the cortical DCX ${ }^{+}$ neurons (again, mostly large, type 2 cells; Fig. $8 C$ ). In parallel, subpopulations of $\mathrm{DCX}^{+}$cells in all regions investigated were immunoreactive for PSA-NCAM, a marker of immaturity expressed by cells retaining plasticity (Bonfanti, 2006). Unlike newly generated neuroblasts of the classic neurogenic sites (SVZ and dentate gyrus), which are mostly PSA-NCAM immunoreactive in cortex, amygdala, claustrum, and external capsule, the staining was detectable only in some $\mathrm{DCX}^{+}$cells, being restricted to parts of their membrane (Fig. 8D). A similar pattern was observed with the A3 subunit of the cyclic nucleotide-gated ion channel (CNGA3; Fig. 8E), which was shown previously in immature cortical neurons (Varea et al., 2011) and is considered to be involved in brain plasticity (Michalakis et al., 2011). The results obtained with the above-mentioned markers were substantially similar in all regions and ages considered. Many DCX ${ }^{+}$ cells (of both types) also expressed markers of immaturity, whereas only small subpopulations (NeuN, mainly type 2 cells) or a few of them (HUC/D) expressed markers of differentiation/maturity (summarized in Fig. $8 F$ ).

After the prenatal origin of the parenchymal DCX ${ }^{+}$cells was assessed, the embryologic divisions (neural progenitor domains) of their origin were investigated by using two markers of pallial (T-box transcription factor, Tbr1) and subpallial (zinc-finger protein, $S p 8$; experiments performed on neonates) origin. The presence of these two proteins was analyzed in the various areas investigated. As reported previously in other mammals, Tbr1 was present in pallial derivatives such as the hippocampus, claustrum, amygdala, and piriform cortex, being frequently associated with the $\mathrm{DCX}^{+}$neurons (Fig. 9). In the neocortex, Tbr1 was strongly expressed in deeper layers with respect to upper layers (where it was mainly found in type 1 cells of the layer II; Fig. 9A). Interestingly, in cortical upper layers, this transcription factor is downregulated during neuronal maturation, at least in mice (Toma et al., 2014). Only rare cells were positive for $S p 8$ in these two regions $(2.2 \%$ in cortex and $1.4 \%$ in claustrum). In contrast, the situation was more heterogeneous in the external capsule and amygdala: two intermixed but distinct cell populations were immunopositive for each one of the two markers, with a prevalence of $\mathrm{Tbr} 1^{+}$cells (Fig. 9B). These results strongly support the view that the $\mathrm{DCX}^{+}$immature cells in subcortical regions are generated from both subpallial and pallial regions $(\sim 25 \%$ and $75 \%$, respectively) of the embryonic SVZ.

\section{Discussion}

The cytoskeletal protein DCX is associated with neuronal maturation and cell shape global remodeling and thus is involved in structural plasticity (Nacher et al., 2001; Brown et al., 2003). For decades, much attention was drawn to adult neurogenesis as a striking process of plasticity involving the production of new neurons that affect learning and memory, also opening possibilities for brain repair (Martino et al., 2011; Peretto and Bonfanti,
2014; Berninger and Jessberger, 2016). In mammals, the functional integration of newborn neurons is highly restricted to olfactory bulb and hippocampus (Bonfanti-and Peretto, 2011), their stem cell niches being less active in humans than in rodents (Sanai et al., 2011; Lipp and Bonfanti, 2016). An emerging form of plasticity consists of cells retaining features of immaturity through adulthood, including the persistent expression of DCX, although they are not generated de novo postnatally ("immature neurons"; GomezCliment et al., 2008). Originally, these cells were described in the paleocortex of rodents (Seki and Arai, 1991; Bonfanti-et al., 1992). Their distribution and role remain largely object of investigation, with systematic studies being scarce (Bonfanti-and Nacher, 2012; König et al., 2016). In some mammals, similar cells are also present in neocortex (Xiong et al., 2008; Cai et al., 2009; Luzzati et al., 2009; Zhang et al., 2009), leading to speculate that non-neurogenic structural plasticity might be prominent in non-rodent species (Bonfanti, 2016 and present work).

We screened the occurrence, location, distribution, and developmental origin of DCX ${ }^{+}$cells as an indicator of non-neurogenic plasticity in sheep: long-living mammals endowed with relatively large-sized, gyrencephalic brains. Using markers of cell division (Ki-67) and pulse labeling of BrdU, we revealed the presence of abundant $\mathrm{DCX}^{+}$cell populations born prenatally and not generated after birth. These cells were not restricted to cerebral cortex; they also occurred in white and gray matter of the following pallial subcortical regions: external capsule, claustrum, and amygdala. In contrast to the substantial decrease in number of $\mathrm{DCX}^{+}$cortical neurons at increasing ages (Abrous et al., 1997; Xiong et al., 2008; Cai et al., 2009; Varea et al., 2009), here confirmed in sheep, the subcortical DCX ${ }^{+}$cells appear steadily maintained through time, at least in young adults (Figs. 6, 10). Groups of $\mathrm{DCX}^{+}$cells were previously found close to the external capsule in rabbits (Luzzati et al., 2003) and in the amygdala of nonhuman primates (Zhang et al., 2009; deCampo et al., 2012). A small portion of them were considered as newly generated in the amygdala of rabbits (Luzzati et al., 2003), mice (Jhaveri et al., 2017), and primates (Bernier et al., 2002). Our experiments in the sheep excluded the occurrence of adult newly born neurons in any of the parenchymal regions containing $\mathrm{DCX}^{+}$cells, thus revealing species-specific heterogeneity in their regional distribution.

As to the maturational stage of the cells, many of them expressed the markers of immaturity/plasticity PSA-NCAM and CNGA3 in addition to DCX. Also, Tbr1 expression in DCX ${ }^{+}$ cortical cells (mainly of type 1) in layer II (wherein the transcription factor is usually downregulated with maturation; see Toma et al., 2014) further supports their immature state. Conversely, the vast majority $(\sim 90 \%)$ did not express NeuN, a soluble nuclear protein with immunoreactivity that becomes obvious as neurons are initiating cellular differentiation (Mullen et al., 1992), and only a few of them did express HuC/D. The small percentage of $\mathrm{DCX}^{+}$cells that express markers of differentiation/maturity (mainly those with complex morphology) are likely in a state ready for further differentiation. In cortex and amygdala, their morphology is reminiscent of the principal cell type (Washburn and Moises, 1992). Therefore, most of the $\mathrm{DCX}^{+}$cells appear to be in an intermediate state of immaturity (Fig. $8 F$ ). Theoretically, they may either be adult "immature neurons" in standby mode or adult neurons undergoing structural plasticity (i.e., a "dematuration and rematuration" process akin to dedifferentiation and redifferentiation). Due to obvious difficulties in performing functional experimental tests in sheep, these latter options remain hypothetical. However, these results, including the fact that immature cell populations in subcortical regions appear more 
A
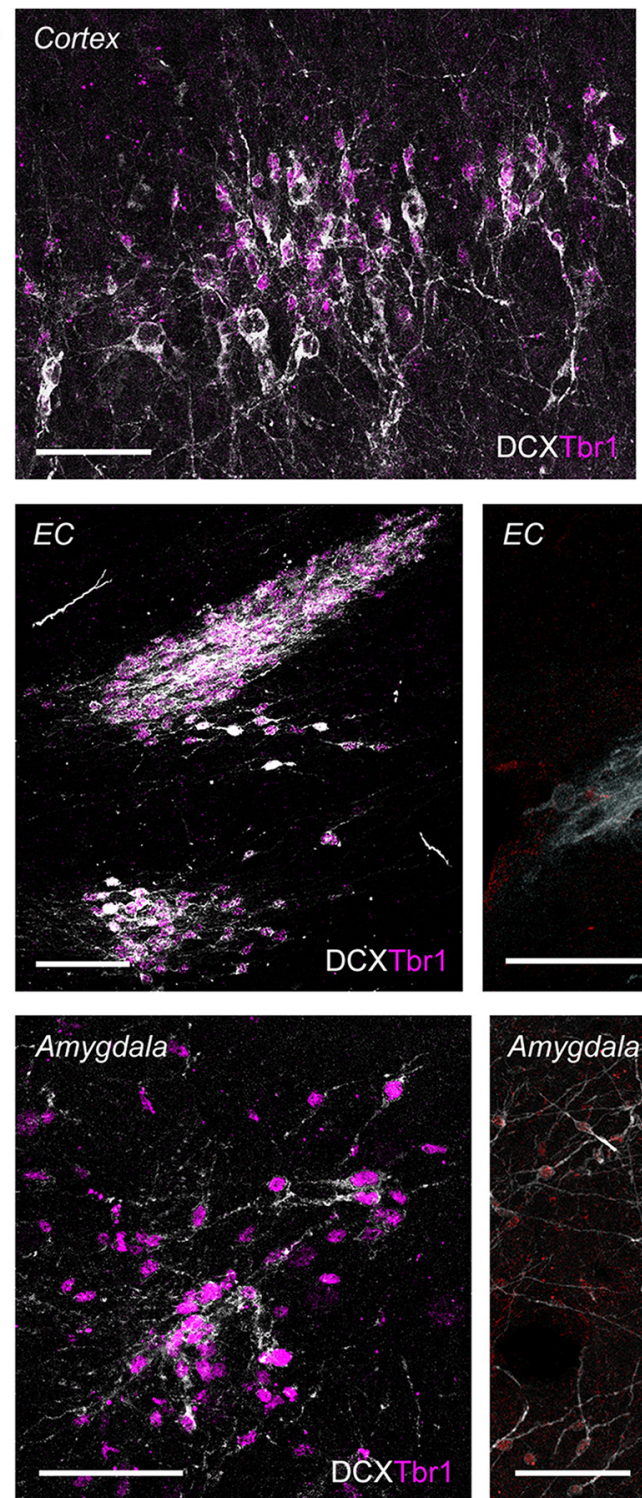

B

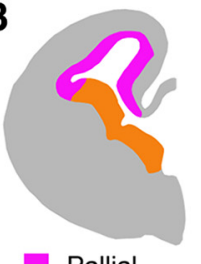

Pallial

Subpallial

\}$_{D C X}+$ cell

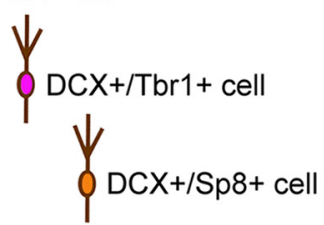

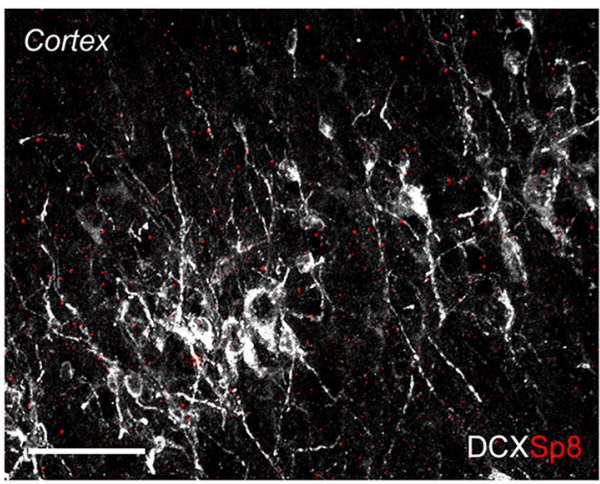
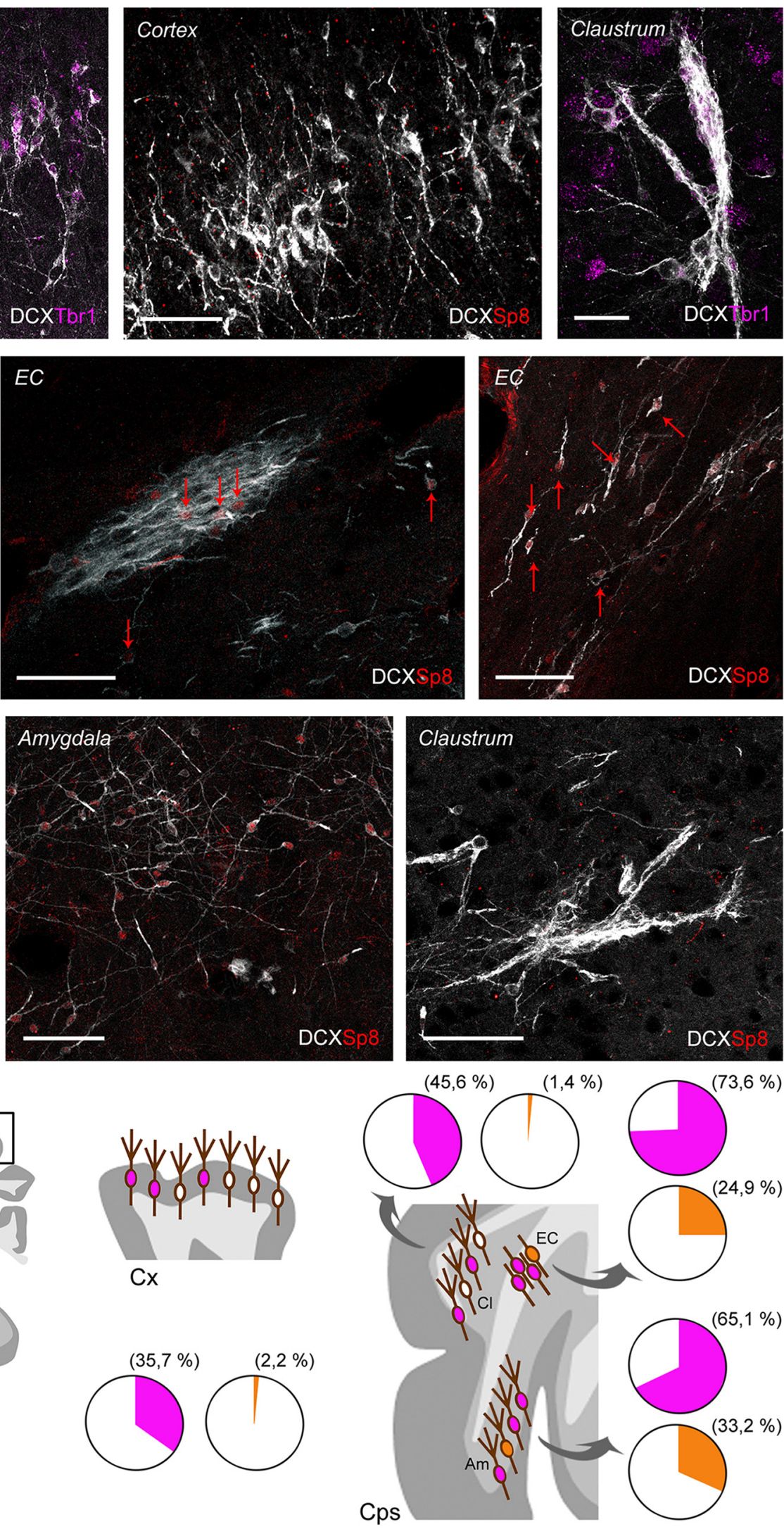

Figure 9. Origin of $\mathrm{DCX}{ }^{+}$cells by detection of pallial/subpallial markers in the neonatal sheep brain. $A$, Distribution of $T b r 1$ and Sp8 proteins in different $D C X^{+}$cell populations of the cerebral cortex, claustrum, external capsule, and amygdala; DCX, white; Tbr1, purple; Sp8, red. Scale bars, $30 \mu \mathrm{m}$. B. Schematic summary of pallial (purple; SVZ counterpart of dorsal, ventral, lateral, and medial pallium) and subpallial (yellow; lateral and medial ganglionic eminences) origin of the $D C X^{+}$cells in cortical (Cx) and capsular/pericapsular structures (Cps). Quantification results are reported in pie charts; most of the DCX ${ }^{+}$cells in cortex and claustrum are only $\mathrm{Tbr}^{+}{ }^{+}$, whereas a mixture of $\mathrm{Tbr} 1^{+}$and $\mathrm{Sp} 8^{+}$cell populations is detectable in the external capsule and amygdaloid nuclei. 
A

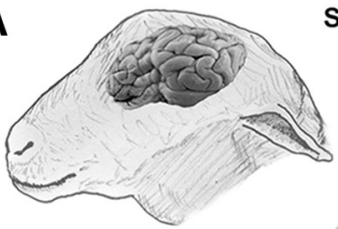

Sites of non-neurogenic structural plasticity

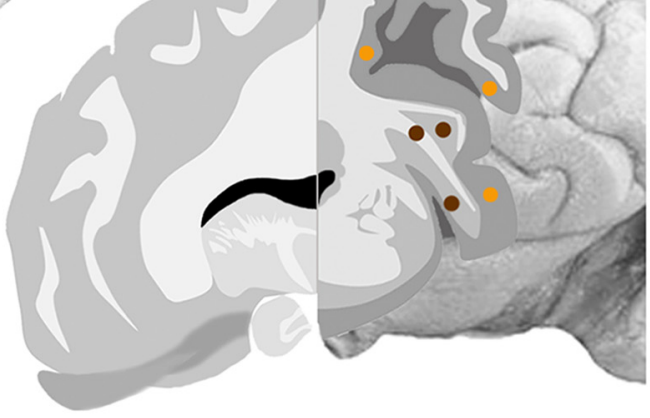

Cortical layer II DCX+ immature neurons

Capsular/pericapsular DCX+ cells

Adult neurogenesis
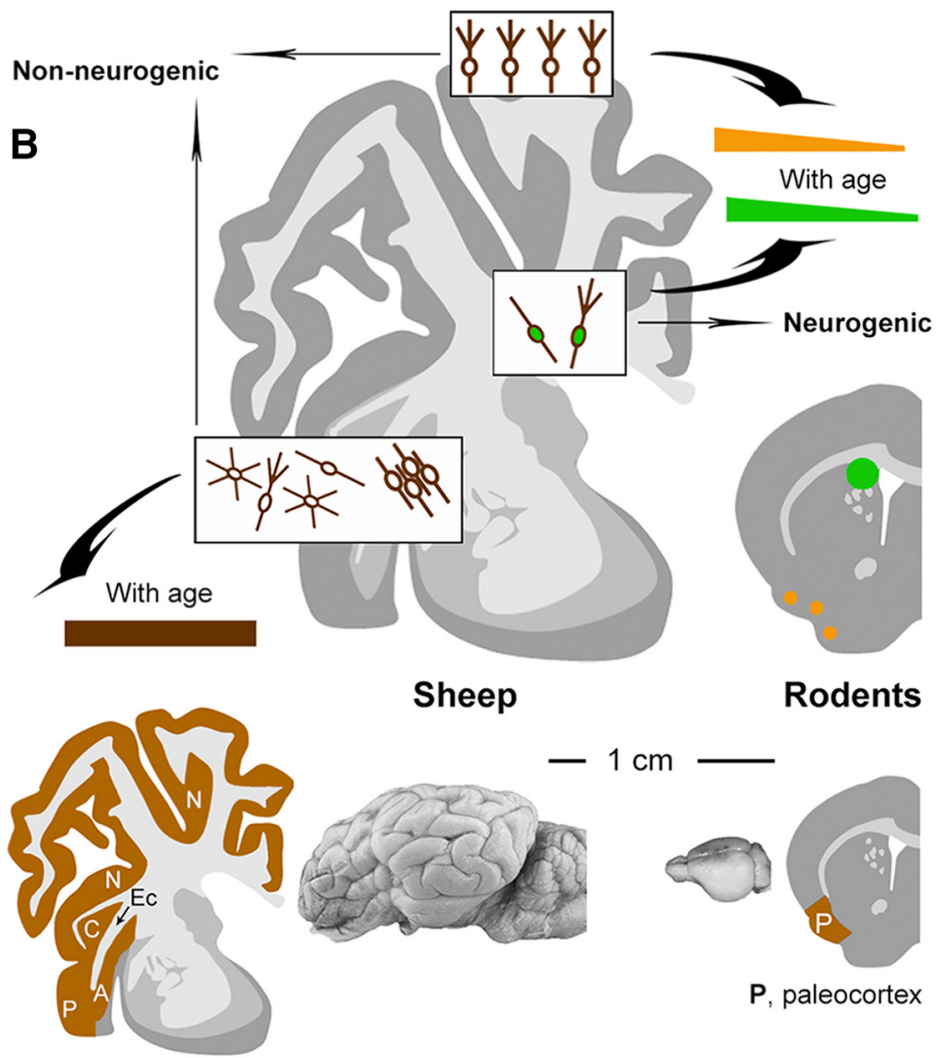

Sheep

Rodents

$\mathbf{P}$, paleocortex

$\mathbf{N}$, neocortex

Ec, external capsule

A, amygdala

C, claustrum

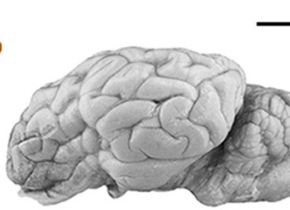

$1 \mathrm{~cm}$

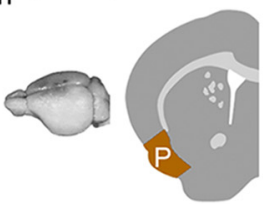

$\mathrm{P}$, paleocortex

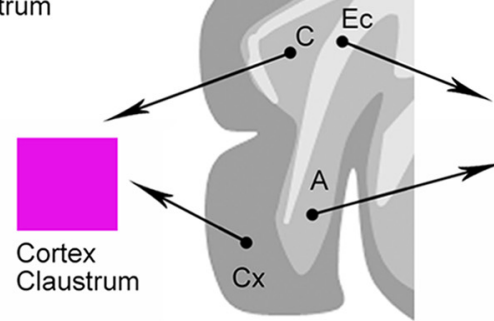

Pallial

Subpallial

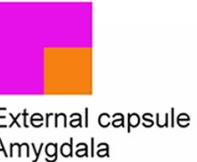

Figure 10. Summary and comparative aspects. $A$, Two main populations of non-newly generated, "immature" $D C X{ }^{+}$cells are present in the cerebral cortex and capsular/pericapsular regions of the sheep brain. $\boldsymbol{B}$, Unlike newly generated neuroblasts of the main neurogenic sites and immature neurons of the cortical layer II, which are consistently reduced with age (Fig. 5), the number stable over time with respect to their cortical counterpart, open new possibilities for the existence of unusual/unknown forms of plasticity in multiple brain regions of nonrodent mammals. The fact that "immature" cell populations in the sheep brain are not regionally restricted like they are in rodents confirms that non-neurogenic structural plasticity might be higher in nonrodent species (Bonfanti-and Nacher, 2012; Fig. 10). Because adult neurogenesis is well preserved in rodents and highly reduced in species evolutionarily and structurally closer to humans (Sanai et al., 2011; Parolisi et al., 2015, 2017; Paredes et al., 2016; Lipp and Bonfanti, 2016), we suggest that non-neurogenic plasticity might have been preserved better in long-living, large-brained mammals (though only studies through mammalian orders might identify putative phylogenetic trends).

Markers of pallial/subpallial origin were used to gain insight into the embryologic origin and, to a lesser extent, the possible fate of the $\mathrm{DCX}^{+}$cells described here. According to the tetrapartite model of pallial subdivision in vertebrate brain, four main territories of progenitor domains can be recognized in pallial germinative regions: medial, dorsal, lateral, and ventral pallium (Holmgren, 1925; Puelles et al., 2000). Tbr1 is a neuron-specific, postmitotic transcription factor mostly found in pallium-derived neurons committed to differentiate into excitatory glutamatergic neurons (Puelles et al., 2000; Bedogni et al., 2010; McKenna et al., 2011). Most of the $\mathrm{DCX}^{+}$cells described here in cortical and subcortical regions expressed Tbrl, so they belong to the glutamatergic principal cortical cells of pallial origin (Hevner et al., 2001). Whereas, in rodents, the $\mathrm{DCX}^{+}$immature neurons are confined in the ventral pallial derivative (paleocortex), we show that immature neurons in sheep extend into other ventral (amygdala), dorsal (neocortex), and lateral (clastrum) pallial derivatives. In the external capsule and amygdala, part of the $\mathrm{DCX}^{+}$cells expressed $S p 8$, a transcription factor marking specific populations of olfactory bulb interneurons that is strongly expressed in

$\leftarrow$

of $D C X^{+}$cells in the sheep capsular/pericapsular regions does not vary from neonatal to adult age. Compared with results reported for laboratory rodents, our findings in sheep strongly suggests that parenchymal, non-neurogenic structural plasticity (brown areas) can be maintained/increased in largebrained, long -living mammals, thus following an opposite trend with respect to adult neurogenesis (green). C, Pallial and mixed (pallial and subpallial) origin of the $D C X^{+}$cells in different brain regions. 
the dorsal lateral ganglionic eminence (a subpallium domain; Waclaw et al., 2006) and in one-fifth of adult cortical interneurons (Ma et al., 2012). We show that the vast majority of $\mathrm{DCX}^{+}$cortical and claustrum neurons in sheep are of pallial origin, whereas capsular and amygdalar $\mathrm{DCX}^{+}$cells are of mixed origin (pallial and nonpallial sources). Therefore, it is very likely that capsular and pericapsular immature neurons derive from different populations during embryogenesis, although genetic lineage tracing would be required to confirm this. Because the anlage of the external capsule is a migration route for $\mathrm{Tbr}^{+}$and $\mathrm{Sp} 8^{+}$cells directed to claustrum and amygdala (Waclaw et al., 2006; Puelles et al., 2017), the DCX ${ }^{+}$ cells in subcortical regions might represent a remnant of immature cells remaining in the white matter during postnatal brain growth.

As to the possible function of the DCX ${ }^{+}$"immature" neurons, no substantial insights have been obtained until now, even in rodents. In the rat paleocortex, they are considered as a reservoir of undifferentiated elements somehow kept in a "stand-by" mode (Gomez-Climent et al., 2008). The current hypothesis (utterly theoretical) is that they might lose immaturity at a certain point of life, possibly integrating in the neural circuits by accomplishing their differentiation (Bonfanti-and Nacher, 2012). In brain regions hosting adult neurogenesis (olfactory bulb, hippocampus), young neurons are endowed with special plastic properties enabling them to affect neural functions substantially and independently from their long-term integration (Stone et al., 2011; Ishikawa et al., 2014). Therefore, an intriguing possibility is that, in some mammals, other pallial regions may foster related types of plasticity by extending the immature phase of specific neuronal subpopulations without the need for increasing their number. In the cortex, immature Tbr1/DCX ${ }^{+}$neurons gradually fade off during postnatal life (Abrous et al., 1997; Xiong et al., 2008; Cai et al., 2009; this study), suggesting that they could be related to cortical maturation. The reason that the number of $\mathrm{DCX}^{+}$cells in claustrum and amygdala remain strikingly constant during postnatal stages is puzzling. These cells may represent a specific subpopulation that express DCX constitutively throughout life and support a form of plasticity that is independent from the general trend of maturation-related structural plasticity. All brain structures hosting the $\mathrm{DCX}^{+}$immature neurons mediate high cognitive functions, including learning, memory, and emotional activities. The amygdala has an essential role in the formation of emotion-related memories (LaBar and Phelps, 1998), whereas the claustrum is considered important in consciousness (Crick and Koch, 2005). Finally, an important subject for future research will be to determine the evolutionary relationships of the $\mathrm{DCX}^{+}$ cells. $\mathrm{Tbr} 1^{+} / \mathrm{DCX}^{+}$cells are present in pallial derivatives of reptiles (including the dorsal ventricular ridge, a ventral pallial derivative homologous of the amygdala; Puelles et al., 2017), leading to the proposal that they could represent a conserved pallial cell type (Luzzati, 2015). Collectively, these observations support the possibility that a population of slowly maturing $\mathrm{DCX}^{+}$cells might be shared by multiple pallial domains being conserved during evolution despite the profound functional/anatomical changes. Independently from any specific function, "immature" neurons raise interest in the general context of mammalian structural plasticity, representing an endogenous reserve of potentially plastic cells.

\section{References}

Abrous DN, Montaron MF, Petry KG, Rougon G, Darnaudéry M, Le Moal M, Mayo W (1997) Decrease in highly polysialylated neuronal cell adhesion molecules and in spatial learning during ageing are not correlated. Brain Res 744:285-292. CrossRef Medline
Aimone JB, Li Y, Lee SW, Clemenson GD, Deng W, Gage FH (2014) Regulation and function of adult neurogenesis: from genes to cognition. Physiol Rev 94:991-1026. CrossRef Medline

Bailey CH, Kandel ER, Harris KM (2015) Structural components of synaptic plasticity and memory consolidation. Cold Spring Harb Perspect Biol 7:a021758. CrossRef Medline

Barami K, Iversen K, Furneaux H, Goldman SA (1995) Hu protein as an early marker of neuronal phenotypic differentiation by subependymal zone cells of the adult songbird forebrain. J Neurobiol 28:82-101. CrossRef Medline

Bedogni F, Hodge RD, Elsen GE, Nelson BR, Daza RA, Beyer RP, Bammler TK, Rubenstein JL, Hevner RF (2010) Tbrl regulates regional and laminar identity of postmitotic neurons in developing neocortex. Proc Natl Acad Sci U S A 107:13129-13134. CrossRef Medline

Bernier PJ, Bedard A, Vinet J, Levesque M, Parent A (2002) Newly generated neurons in the amygdala and adjoining cortex of adult primates. Proc Natl Acad Sci U S A 99:11464-11469. CrossRef Medline

Berninger B, Jessberger S (2016) Engineering of adult neurogenesis and gliogenesis. Cold Spring Harb Perspect Biol 8: pii: a018861. CrossRef Medline

Beul SF, Hilgetag CC (2014) Towards a "canonical" agranular cortical microcircuit. Front Neuroanat 8:165. CrossRef Medline

Bonfanti-L (2006) PSA-NCAM in mammalian structural plasticity and neurogenesis. Prog Neurobiol 80:129-164. CrossRef Medline

Bonfanti-L (2016) Adult neurogenesis 50 years later: Limits and opportunities in mammals. Front Neurosci 10:44. CrossRef Medline

Bonfanti-L, Nacher J (2012) New scenarios for neuronal structural plasticity in non-neurogenic brain parenchyma: the case of cortical layer II immature neurons. Prog Neurobiol 98:1-15. CrossRef Medline

Bonfanti-L, Peretto P (2011) Adult neurogenesis in mammals: a theme with many variations. Eur J Neurosci 34:930-950. CrossRef Medline

Bonfanti-L, Theodosis DT (2009) Polysialic acid and activity-dependent synapse remodeling. Cell Adh Migr 3:43-50. CrossRef Medline

Bonfanti-L, Olive S, Poulain DA, Theodosis DT (1992) Mapping of the distribution of polysialylated neural cell adhesion molecule throughout the central nervous system of the adult rat: an immunohistochemical study. Neuroscience 49:419-436. CrossRef Medline

Brown JP, Couillard-Després S, Cooper-Kuhn CM, Winkler J, Aigner L, Kuhn HG (2003) Transient expression of doublecortin during adult neurogenesis. J Comp Neurol 467:1-10. CrossRef Medline

Brus M, Meurisse M, Franceschini I, Keller M, Lévy F (2010) Evidence for cell proliferation in the sheep brain and its down-regulation by parturition and interactions with the young. Horm Behav 58:737-746. CrossRef Medline

Brus M, Keller M, Lévy F (2013a) Temporal features of adult neurogenesis: differences and similarities across mammalian species. Front Neurosci 7:135-144. CrossRef Medline

Brus M, Meurisse M, Gheusi G, Keller M, Lledo PM, Lévy F (2013b) Dynamics of olfactory and hippocampal neurogenesis in adult sheep. J Comp Neurol 521:169-188. CrossRef Medline

Cai Y, Xiong K, Chu Y, Luo DW, Luo XG, Yuan XY, Struble RG, Clough RW, Spencer DD, Williamson A, Kordower JH, Patrylo PR, Yan XX (2009) Doublecortin expression in adult cat and primate cerebral cortex relates to immature neurons that develop into GABAergic subgroups. Exp Neurol 216:342-356. CrossRef Medline

Crick FC, Koch C (2005) What is the function of the claustrum? Philos Trans R Soc Lond B Biol Sci 360:1271-1279. CrossRef Medline

deCampo DM, Fudge JL (2012) Where and what is the paralaminar nucleus? A review on a unique and frequently overlooked area of the primate amygdala. Neurosci Biobehav Rev 36:520-535. CrossRef Medline

Feliciano DM, Bordey A, Bonfanti-L (2015) Noncanonical Sites of Adult Neurogenesis in the Mammalian Brain. Cold Spring Harb Perspect Biol 7:a018846. CrossRef Medline

Frotscher M (1992) Specificity of interneuronal connections. Ann Anat 174: 377-382. CrossRef Medline

Gleeson JG, Lin PT, Flanagan LA, Walsh CA (1999) Doublecortin is a microtubule-associated protein and is expressed widely by migrating neurons. Neuron 23:257-271. CrossRef Medline

Gómez-Climent MA, Castillo-Gómez E, Varea E, Guirado R, Blasco-Ibáñez JM, Crespo C, Martínez-Guijarro FJ, Nácher J (2008) A population of prenatally generated cells in the rat paleocortex maintains an immature neuronal phenotype into adulthood. Cereb Cortex 18:2229-2240. CrossRef Medline 
Grandel H, Brand M (2013) Comparative aspects of adult neural stem cell activity in vertebrates. Dev Genes Evol 223:131-147. CrossRef Medline

Hevner RF, Shi L, Justice N, Hsueh Y, Sheng M, Smiga S, Bulfone A, Goffinet AM, Campagnoni AT, Rubenstein JL (2001) Tbr1 regulates differentiation of the preplate and layer 6. Neuron 29:353-366. CrossRef Medline

Holmgren N (1925) Points of view concerning forebrain morphology in higher vertebrates. Acta Zool Stockh 6:413-477. CrossRef

Ishikawa R, Kim R, Namba T, Kohsaka S, Uchino S, Kida S (2014) Timedependent enhancement of hippocampus-dependent memory after treatment with memantine: Implications for enhanced hippocampal adult neurogenesis. Hippocampus 24:784-793. CrossRef Medline

Jhaveri DJ, Tedoldi A, Hunt S, Sullivan R, Watts NR, Power JM, Bartlett PF, Sah P (2017) Evidence for newly generated interneurons in the basolateral amygdala of adult mice. Mol Psychiatry. In press. CrossRef Medline

Kempermann G, Jessberger S, Steiner B, Kronenberg G (2004) Milestones of neuronal development in the adult hippocampus. Trends Neurosci 27:447-452. CrossRef Medline

König R, Benedetti B, Rotheneichner P, O’Sullivan A, Kreutzer C, Belles M, Nacher J, Weiger TM, Aigner L, Couillard-Després S (2016) Distribution and fate of DCX/PSA-NCAM expressing cells in the adult mammalian cortex: a local reservoir for adult cortical neuroplasticity? Front Biol 11:193-213. CrossRef

LaBar KS, Phelps EA (1998) Role of the human amygdala in arousal mediated memory consolidation. Psychol Sci 9:490-493. CrossRef

Lipp HP, Bonfanti-L (2016) Adult neurogenesis in mammals: variations and confusions. Brain Behav Evol 87:205-221. CrossRef Medline

Lois C, García-Verdugo JM, Alvarez-Buylla A (1996) Chain migration of neuronal precursors. Science 271:978-981. CrossRef Medline

Luzzati F (2015) A hypothesis for the evolution of the upper layers of the neocortex through co-option of the olfactory cortex developmental program. Front Neurosci 9:162. CrossRef Medline

Luzzati F, Peretto P, Aimar P, Ponti G, Fasolo A, Bonfanti-L (2003) Gliaindependent chains of neuroblasts through the subcortical parenchyma of the adult rabbit brain. Proc Natl Acad Sci U S A 100:13036-13041. CrossRef Medline

Luzzati F, Bonfanti-L, Fasolo A, Peretto P (2009) DCX and PSA-NCAM expression identifies a population of neurons preferentially distributed in associative areas of different pallial derivatives and vertebrate species. Cereb Cortex 19:1028-1041. CrossRef Medline

Ma T, Zhang Q, Cai Y, You Y, Rubenstein JL, Yang Z (2012) A subpopulation of dorsal lateral/caudal ganglionic eminence-derived neocortical interneurons expresses the transcription factor Sp8. Cereb Cortex 22: 2120-2130. CrossRef Medline

Marqués-Marí AI, Nacher J, Crespo C, Gutièrrez-Mecinas M, MartínezGuijarro FJ, Blasco-Ibáñez JM (2007) Loss of input from the mossy cells blocks maturation of newly generated granule cells. Hippocampus 17: 510-524. CrossRef Medline

Martino G, Pluchino S, Bonfanti-L, Schwartz M (2011) Brain regeneration in physiology and pathology: the immune signature driving therapeutic plasticity of neural stem cells. Physiol Rev 91:1281-1304. CrossRef Medline

McKenna WL, Betancourt J, Larkin KA, Abrams B, Guo C, Rubenstein JL, Chen B (2011) Tbr1 and Fezf2 regulate alternate corticofugal neuronal identities during neocortical development. J Neurosci 31:549-564. CrossRef Medline

Michalakis S, Kleppisch T, Polta SA, Wotjak CT, Koch S, Rammes G, Matt L, Becirovic E, Biel M (2011) Altered synaptic plasticity and behavioral abnormalities in CNGA3-deficient mice. Genes Brain Behav 10:137-148. CrossRef Medline

Mullen RJ, Buck CR, Smith AM (1992) NeuN, a neuronal specific nuclear protein in vertebrates. Development 116:201-211. Medline

Nacher J, Bonfanti-L (2015) New neurons from old beliefs in the adult piriform cortex? A commentary on: "Occurrence of new neurons in the piriform cortex". Front Neuroanat 9:62. CrossRef Medline

Nacher J, Crespo C, McEwen BS (2001) Doublecortin expression in the adult rat telencephalon. Eur J Neurosci 14:629-644. CrossRef Medline

Paredes MF, Sorrells SF, Garcia-Verdugo JM, Alvarez-Buylla A (2016) Brain size and limits to adult neurogenesis. J Comp Neurol 524:646-664. CrossRef Medline

Parolisi R, Peruffo A, Messina S, Panin M, Montelli S, Giurisato M, Cozzi B, Bonfanti-L (2015) Forebrain neuroanatomy of the neonatal and juvenile dolphin (T. truncatus and S. coeruloalba). Front Neuroanat 9:140. CrossRef Medline

Parolisi R, Cozzi B, Bonfanti-L (2017) Non-neurogenic SVZ-like niche in dolphins, mammals devoid of olfaction. Brain Struct Funct 222:26252639. CrossRef Medline

Peretto P, Bonfanti-L (2014) Major unsolved points in adult neurogenesis: doors open on a translational future? Front Neurosci 8:154. CrossRef Medline

Ponti G, Aimar P, Bonfanti-L (2006) Cellular composition and cytoarchitecture of the rabbit subventricular zone (SVZ) and its extensions in the forebrain. J Comp Neurol 498:491-507. CrossRef Medline

Puelles L, Kuwana E, Puelles E, Bulfone A, Shimamura K, Keleher J, Smiga S, Rubenstein JL (2000) Pallial and subpallial derivatives in the embryonic chick and mouse telencephalon, traced by the expression of the genes $D l x-2$, Emx-1, Nkx-2.1, Pax-6, and Tbr-1. J Comp Neurol 424:409-438. CrossRef Medline

Puelles L, Sandoval JE, Ayad A, del Corral R, Alonso A, Ferran JL, Martınezde-la-Torre M (2017) The pallium in reptiles and birds in the light of the updated tetrapartite pallium model. In: Evolution of nervous systems, Ed 2, Vol 1 (Kaas JH, editor). New York, NY: Elsevier.

Sanai N, Nguyen T, Ihrie RA, Mirzadeh Z, Tsai HH, Wong M, Gupta N, Berger MS, Huang E, Garcia-Verdugo JM, Rowitch DH, Alvarez-Buylla A (2011) Corridors of migrating neurons in the human brain and their decline during infancy. Nature 478:382-386. CrossRef Medline

Seki T, Arai Y (1991) Expression of highly polysialylated NCAM in the neocortex and piriform cortex of the developing and the adult rat. Anat Embryol (Berl) 184:395-401. CrossRef Medline

Stone SS, Teixeira CM, Zaslavsky K, Wheeler AL, Martinez-Canabal A, Wang AH, Sakaguchi M, Lozano AM, Frankland PW (2011) Functional convergence of developmentally and adult-generated granule cells in dentate gyrus circuits supporting hippocampus-dependent memory. Hippocampus 21:1348-1362. CrossRef Medline

Theodosis DT, Poulain DA, Oliet SH (2008) Activity-dependent structural and functional plasticity of astrocyte-neuron interactions. Physiol Rev 88:983-1008. CrossRef Medline

Toma K, Kumamoto T, Hanashima C (2014) The timing of upper-layer neurogenesis is conferred by sequential derepression and negative feed back from deep-layer neurons. J Neurosci 34:13259-13276. CrossRef Medline

Varea E, Castillo-Gomez E, Gomez-Climent MA, Guirado R, Blasco-Ibanez JM, Crespo C, Martinez-Guijarro FJ, Nacher J (2009) Differential evolution of PSANCAM expression during aging of the rat telencephalon. Neurobiol Aging 5:808-818. CrossRef Medline

Varea E, Belles M, Vidueira S, Blasco-Ibáñez JM, Crespo C, Pastor AM, Nacher J (2011) PSA-NCAM is expressed in immature, but not recently generated, neurons in the adult cat cerebral cortex layer II. Front Neurosci 5:17. CrossRef Medline

Waclaw RR, Allen ZJ 2nd, Bell SM, Erdélyi F, Szabó G, Potter SS, Campbell K (2006) The zinc finger transcription factor Sp8 regulates the generation and diversity of olfactory bulb interneurons. Neuron 49:503-516. CrossRef Medline

Washburn MS, Moises HC (1992) Electrophysiological and morphological properties of rat basolateral amygdaloid neurons in vitro. J Neurosci 12: 4066-4079. Medline

Xiong K, Luo DW, Patrylo PR, Luo XG, Struble RG, Clough RW, Yan XX (2008) Doublecortin-expressing cells are present in layer II across the adult guinea pig cerebral cortex: Partial colocalization with mature interneuron markers. Exp Neurol 211:271-282. CrossRef Medline

Zhang XM, Cai Y, Chu Y, Chen EY, Feng JC, Luo XG, Xiong K, Struble RG, Clough RW, Patrylo PR, Kordower JH, Yan XX (2009) Doublecortinexpressing cells persist in the associative cerebral cortex and amygdala in aged nonhuman primates. Front Neuroanat 3:17. CrossRef Medline 